\title{
A framework for achieving sustainability by overcoming the challenges of the construction supply chain during the design process
}

DOI 10.2478/otmcj-2021-0008

Received January 15, 2020; accepted: July 17, 2020

\begin{abstract}
This paper aims to develop a framework to achieve sustainability by overcoming the challenges of the construction supply chain (CCSC) during the design process. To achieve this, two approaches, namely theoretical and practical, were used to accomplish four objectives. For the theoretical approach, based on literature review and case studies, the objective used was to identify, classify and validate the challenges that the construction supply chain (CSC) encounter. For the practical approach, a survey questionnaire was employed to quantify the CCSC and investigate the perception of architectural design firms (ADFs) in Egypt towards achieving sustainability by overcoming the CCSC during the design process. Based on the results, the research developed a framework to overcome the CCSC as an approach towards achieving sustainability in construction projects during the design process. The research identified and validated 20 challenges that the CSC encounter towards achieving sustainability during the design process. These challenges were classified under four categories, namely (1) design and technical process; (2) coordination, information flow and accuracy; (3) material specification, technology, supplier rework and whole life cycle cost; and (4) skills gap of the qualified architects and design managers and non-compliance to building codes, regulations, laws and standards. In addition, a survey questionnaire was employed to rank these challenges according to their importance on 1-5 Likert scale using the measure of central tendency and dispersion and relative importance index (RII).
\end{abstract}

\footnotetext{
*Corresponding author: Ayman Ahmed Ezzat Othman, Architectural Engineering Department, Faculty of Engineering, The British University in Egypt (BUE), El Shorouk City - Cairo Suez Desert Road, Postal No. 11837 - P.O. Box 43, Cairo, Egypt.

E-mail: ayman.othman@bue.edu.eg

Nooran AlNassar, Faculty of Engineering, British University in Egypt, Cairo, Egypt
}

Keywords: challenges, construction supply chain, architectural design firms, the construction industry, sustainability

\section{Introduction}

The construction industry plays a significant role in the social and economic development of the countries worldwide. Socially, it provides societies with projects and infrastructure facilities that fulfil their needs and enhance the living standards and quality of people's life (Friends of the Earth, 1995; Roodman and Lenssen, 1995; Khan, 2008). Economically, it provides most of the countries' fixed capital assets, increases gross domestic product (GDP), offers job opportunities and supports other industrial sectors to prosper (Field and Ofori, 1988). However, the construction industry has a major impact on the environment. It is estimated that about 3 billion tons of raw materials and $40 \%$ of the total flow of the global economy are used in manufacturing construction materials (Roodman and Lenssen, 1995). Moreover, the construction sector is responsible for $50 \%$ of the material resources extracted from nature, $40 \%$ of energy consumption and $50 \%$ of total waste generated. These unsustainable practices called for the construction industry to be more sustainable (Chileshe, 2011). The construction industry is concerned with translating the client requirements into a design that specifies technical characteristics, functional performance criteria and quality standards and by completing the project within the stipulated time and in most cost- effective manner (Bowen et al., 1999; Broft et al., 2016). These projects are achieved through a network of all parties involved in the project development process (e.g. designer, contractor, supplier, manufacturer, distributer, wholesaler and retailer). The base foundation of this network is the CSC and through its activities, the construction industry can operate. The $\mathrm{CSC}$ is a valuable part of the economy. However, it has been argued that its performance needs to be improved in order to achieve sustainability objectives. Due to the 
diverse nature of the CSC, as it is human-based and consists of intense activities, relationships and operations (Chin et al., 2015), it faces several issues such as uncertainty of the project cost, poor quality, time delay, rework, lack of information, waste generation, and lack of integration and collaboration between different parties (Essam and Ehab, 2015; Simangunsong et al., 2016). It is claimed that the root causes of these issues are found in the design phase (Segerstedt and Olofsson, 2010). This is due to the reason that ADFs are the first line of contact with clients in the construction industry and many of the decisions made during the design phase affect the building performance throughout its life cycle (Othman, 2008). To address this issue, this paper aims to develop a framework to achieve sustainability in construction projects by overcoming the CCSC during the design process. In order to achieve the abovementioned aim, a research methodology consisting of literature review, case studies and survey questionnaire was developed with four objectives to achieve:

a) First, to identify and classify the CCSC by investigating the nature of the construction industry, CSC, sustainability and architectural design process. This objective was achieved through literature review based on textbooks, academic and professional journals, conference and seminar proceedings, dissertations and theses, organisations and government publications as well as Internet and related websites.

b) Second, to validate the identified CCSC by collecting and analysing a number of case studies of the construction projects. The information obtained was classified into two main types: the first being background about the project; and the second concerned with the challenges that the CSC encountered and their impact on the environmental, social and economic aspects of sustainability.

c) Third, to quantify the CCSC and investigate the perception of ADFs towards achieving sustainability through overcoming the CCSC. This objective was achieved by conducting a survey questionnaire with a representative sample of ADFs in Egypt. The survey consisted of three sections: (1) general information about the surveyed firms, (2) ranking of CSCC on 1-5 Likert scale and (3) CSC solution strategies. A pilot study of the survey was tested with colleagues to determine its effectiveness and drawbacks. After going over the responses of the preliminary test and making changes, the questionnaire was ready for formal testing (Baker, 1994; Czaja and Blair, 1996). Copy of the survey questionnaire could be obtained from authors upon request. d) Finally, to develop a framework to achieve sustainability by overcoming the CCSC during the design process (see Figure 1).

\section{Literature review}

\subsection{Nature of the construction industry}

The construction industry and its activities are considered one of the major sources of social development and economic growth of the countries worldwide. It can be regarded as a means of providing communities with projects and infrastructure facilities that fulfil their needs and meet their expectations. In addition, it is a mechanism of generating employment and offering job opportunities to millions of unskilled, semiskilled and skilled workforces. Furthermore, it plays a crucial role in increasing the GDP and supplementing foreign exchange derived from the trade in construction materials and engineering services (Khan, 2008; Essam and Ehab, 2015). However, the construction industry is blamed for being fragmented, risky and complex business. Because getting the project approval from the initial investment appraisal stage to completion and into use involves a complex and time-consuming design and construction process. This involves a multitude of people from various organisations with different skills and interests, and a great deal of effort is required to co-ordinate a wide range of construction activities (Guo et al., 2016). Moreover, the construction industry has a negative impact on the environment. It affects the environment in two ways, namely consuming resources and creating pollution and waste. According to a report prepared by the Willmott Dixon Group (2015), the construction industry accounts for around $45-50 \%$ of global energy usage, nearly 50\% of worldwide water usage and around $60 \%$ of the total usage of raw materials. In addition, the industry causes about $23 \%$ of air pollution, $50 \%$ of climate change gases, $40 \%$ of drinking water contamination and another $50 \%$ of landfill wastes. The increasing attention towards saving the environment called for the construction industry to be more sustainable and to consider the decisions made during the design phase.

\subsection{The construction supply chain}

The concept of the supply chain has been a relatively recent business topic especially when compared to the 


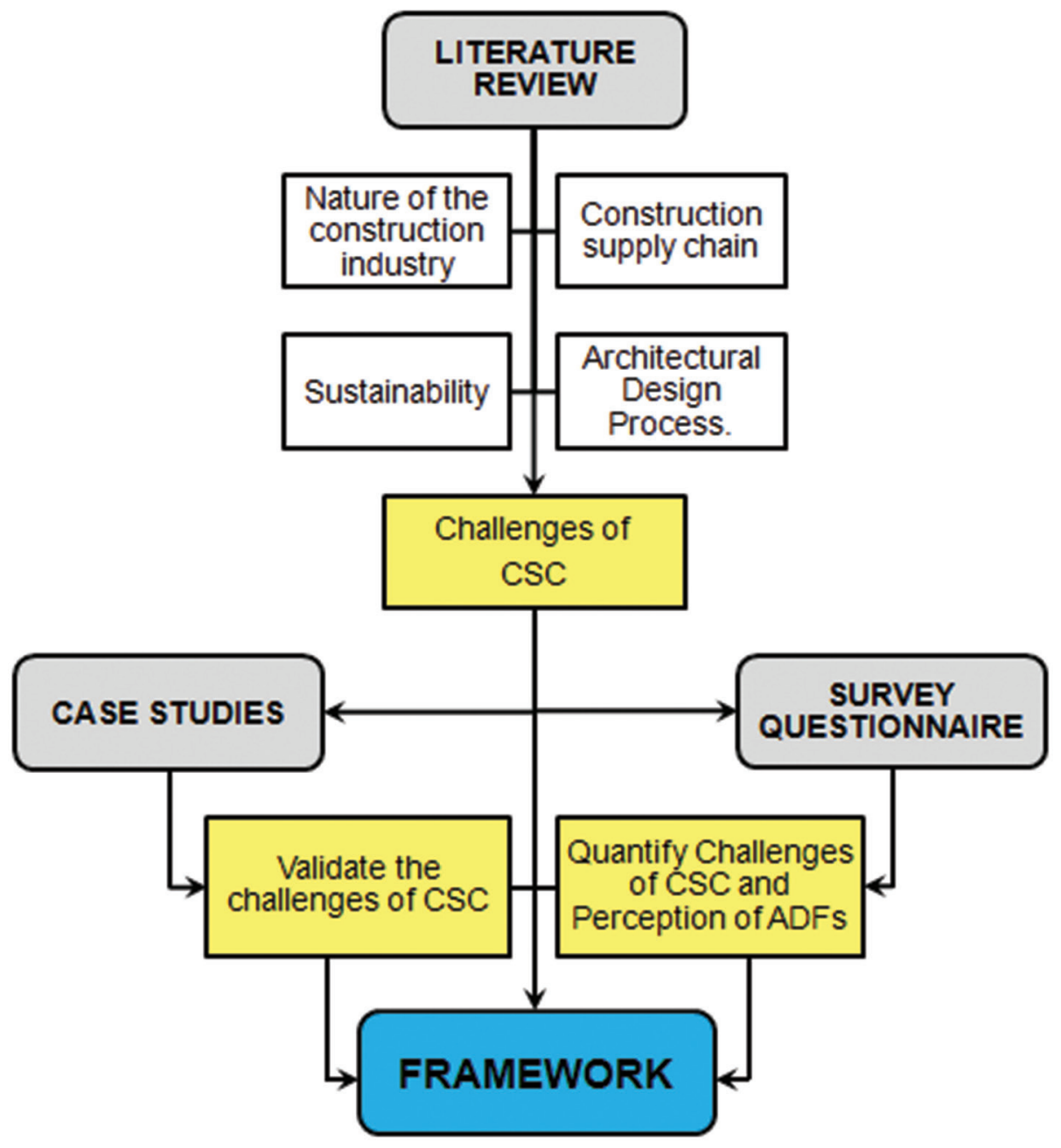

Fig. 1: Research objectives and methodologies.

broader history of manufacturing and commerce. Yet, the actual practice of the supply chain management (SCM) is in operation for many decades, if not centuries (Sarkis, 2014). The supply chain is the network of organisations that are involved directly or indirectly, through upstream (supply) and downstream (distribution) linkages, in the different processes and activities needed to produce value in the form of products and services in the hands of the ultimate customer (Christopher, 1998). It involves the flow and transformation of materials, information and processes into products and services from the involved organisations to the final customer (Chopra and Meindl, 2013). In construction, the supply chain describes the interconnected hierarchy of supply contracts needed to procure a built asset. Managing the supply chain includes the proper understanding of the breakdown and traceability of products, services, organisations, logistics, people, activities, information and resources that transform raw materials into a finished product that fits its purpose. Due to its nature, the construction industry is different from the automotive industry. This is because the construction industry has a distinct difficulty that every building has a unique prototype and was developed by a team of designers, contractors and suppliers that may never have worked together before and may never work together again. In addition, the different procurement approaches adopted in construction place elements of SCM with varying disciplines and organisations. For example, in the traditional procurement approach, the design consultants are the first tier of suppliers, working for the client, and the contractor has a supply chain of subcontractors and specialist suppliers. In the private finance initiative (PFI) and Design and Build projects, there will be the first tier supplier (i.e. contractors) and the design consultants will work for them as part of their supply chain. In large or complex projects, there is plethora of suppliers in every discipline (AlNassar et al., 2018). 


\subsubsection{Types of the supply chain}

Mentzer et al. (2001) identified three different types of supply chains based on the level and the number of organisations involved as follows.

- Basic (direct) supply chain consists of an organisation, an instant supplier and an instant customer, which are directly linked via one of the upstream and downstream flows of products, services, finances and information (see Figure 2).

- Extended supply chain consists of suppliers of the immediate supplier and customers of the immediate customer, which are connected by one or more of the upstream and/or downstream flows of products, services, finances and information (see Figure 3).

- Ultimate supply chain includes all the organisations involved in all the upstream and downstream flows of products, services, finances and information from the ultimate supplier to the ultimate customer (see Figure 4).

\subsubsection{Supply chain management in construction}

The concept of SCM is originally developed in the manufacturing industry. Due to the unique nature of the construction industry, Cox and Townsend (1998) criticised many authors and practitioners in the construction industry for copying the ideas of supply chain partnering from Japanese and Western automotive industries without considering the distinctive nature of both industries. To cope with this difference in nature, great effort was devoted in construction literature to develop an understanding of the SCM in the context of construction. There are several statements and perspectives that defined SCM and explained its contents and objectives, which agreed that the SCM is the system of suppliers and contractors producing, delivering and installing materials for construction projects (O'Brien and Fischer, 1993). It is the establishment, co-ordination and maintenance of an optimised supply chain that operates effectively, fulfilling all its preconditions and goals optimally, and involving all its stakeholders (Vrijhoef, 1998). SCM is the management of all the processes that are required to deliver a service or a product for a customer through a network of organisations with minimum waste and maximum value. It is the practice of a group of companies and individuals working collaboratively in a network of interrelated processes structured to best satisfy end-user needs while rewarding all members of the chain (Arbulu and Tommelein, 2002; Elfving et al., 2005).

\subsubsection{The importance of supply chain management in construction}

Vrijhoef (1998) mentioned that the SCM plays a pivotal role in providing improvement opportunities for all

\section{Supplier}

\section{Organisation}

Customer

Fig. 2: Basic supply chain (adapted from Mentzer et al., 2001).

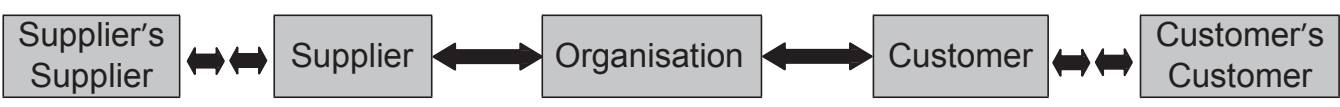

Fig. 3: Extended supply chain (adapted from Mentzer et al., 2001).

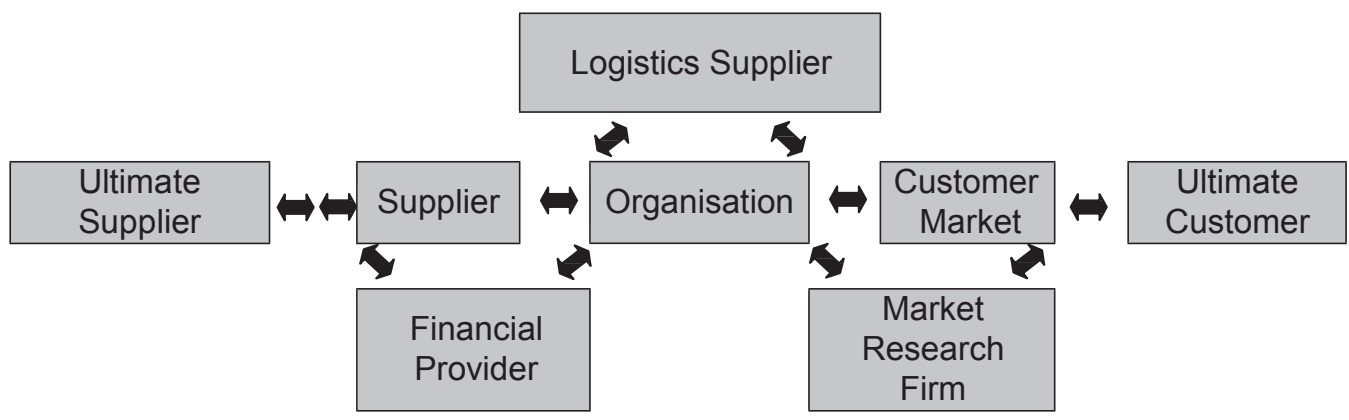

Fig. 4: Ultimate supply chain (adapted from Mentzer et al., 2001). 
problematic issues in the construction industry. It provides strong mechanism for enhancing the cohesion and controllability of the CSC as a whole. It helps optimising the material and information flow in construction projects by means of measurement, redesign and reengineering of the chain process. Moreover, it brings up possibilities to enhance operations, logistics and materials management, and intensify collaboration and communication across the supply chain. Greenwood (2004) proposed that managing the CSC through collaborating has a powerful effect on the areas of cost and cost predictability. It is expected to save approximately $31 \%$ of the tender price. Furthermore, he pointed out that more than $70 \%$ of the project cost is associated with the supply chain (suppliers and subcontractors) rather than the main contractor. This means that effectively managing the supply chain opens up an opportunity for significant reduction in the project's costs. This argument is supported by Edum-Fotwe et al. (1999), who claimed that competition within the construction industry in the next decade or two will be between supply chains, and not among individual companies.

\subsubsection{The focus of supply chain management in construction}

Vrijhoef and Koskela (2000) introduced four major areas of focus of SCM in construction.

a) The first focus is on the impacts of the supply chain on site activities, with the goal of reducing costs and durations of site activities. The main concern is to ensure the flow of materials and labour to the site to avoid disruption to the workflow. The main contractor is in the best position to adopt this focus.

b) The second focus is on the supply chain itself. The goal is to reduce the costs related to logistics, leadtime and inventory. Material and component suppliers may adopt this focus.

c) The third focus is on transferring activities from the site to earlier stages of the supply chain. The goal is to reduce the total costs and duration. This focus may be initiated by suppliers or contractors.

d) The final focus is on the integrated management and improvement of the supply chain and the site production, where site production is subsumed into SCM. This focus may be initiated by clients, suppliers or contractors.

\subsection{Sustainability}

\subsubsection{Background and importance}

In a broad sense, sustainability is the capacity to endure. It aims to create and maintain the social, economic and environmental conditions that enable humans to exist with nature in 'productive harmony' in the present and the future (USEPA, 2009). There are more than 200 different definitions for sustainability (Parkin et al., 2003). This emphasised its importance and showed the efforts made by various academic and practical disciplines to define and understand its implications to their fields. However, all these definitions agree that it is necessary to develop innovative solutions to meet the needs of the present generations without compromising the ability of future generations to meet their own needs (World Commission on Environment and Development, 1987; Boyko et al., 2006). It promotes a balanced approach by taking account of the need to continue in business, but does not seek profitability at the expense of the environmental or societal needs (MaSC, 2002). Despite the valuable contribution of the construction industry towards social development and economic growth, it is a very large consumer of non-renewable resources. It is a substantial source of waste and pollution to air and water as well as land dereliction (Friends of the Earth, 1995; Roodman and Lenssen, 1995). Anink et al. (1996) stated that the construction sector is accountable for $50 \%$ of the material resources taken from nature, $40 \%$ of energy consumption and $50 \%$ of total waste generated. The increasing awareness of sustainability worldwide and its contribution towards saving the environment, prospering economy and enhancing society called for the construction industry to think sustainable (Addis and Talbot, 2001; Abdellatif and Othman, 2006).

\subsubsection{Aspects of sustainability}

Sustainability has three main aspects, namely environmental, social and economic. The interaction between these aspects generated three new aspects, namely social-environmental, environmental-economic and economic-social, which revolve around the rights of all individuals to have a fair share of the natural resources of the environment at national and international levels. This ensures that these environmental resources are not exploited by a portion of the society leaving the rest with needs that cannot be met by the remaining resources (see Figure 5; Rodriguez et al., 2002; 
Karlsson, 2009; Valdés-Rodríguez and Pérez-Vázque, 2011; Othman et al., 2014).

\subsubsection{Benefits of sustainability}

The application of sustainability in construction is reflected in every aspect of the construction process. It includes, for instance, sustainable design, sustainable planning, sustainable architecture, sustainable landscaping and sustainable construction. By applying the concepts of sustainability in the construction industry, a number of benefits will be achieved. Environmentally, sustainability helps in reducing the use of non-renewable resources, minimising environmental risks and uncertainty, reducing waste and pollution and increasing the reuse and recycling of building materials (Kim, 1998). Socially, sustainability focuses on identifying stakeholders' requirements and ensuring that the developed project fulfils their needs and meets their expectations. Moreover, it encourages involvement and getting feedback from all parties affected by the built environment, ensuring the health and safety requirements are achieved, considering people with special needs and providing support and adding value to communities and the supply chain. Economically, sustainability supports growth in the construction industry through increasing GDP, providing more job opportunities, raising the client's profit and investment return (Chen and Chambers, 1999; Addis and Talbot, 2001; WS Atkins Consultants, 2001).

\subsubsection{Sustainable construction supply chain}

Sustainable supply chain has taken multiple forms in literature under the terminologies of green management, green SCM, green supply chain, sustainability and sustainable SCM. The previous terms shared a common goal, which is the management of environmental, social and economic impacts, and the encouragement of good governance practices throughout the life cycles of projects and delivered services. Suppliers in the present-day business environment are taking more responsibility to effectively design, produce and recall their products because the construction industry is becoming more environmentally cautious and the government regulations are put in place accordingly. To achieve that, the CSC should not

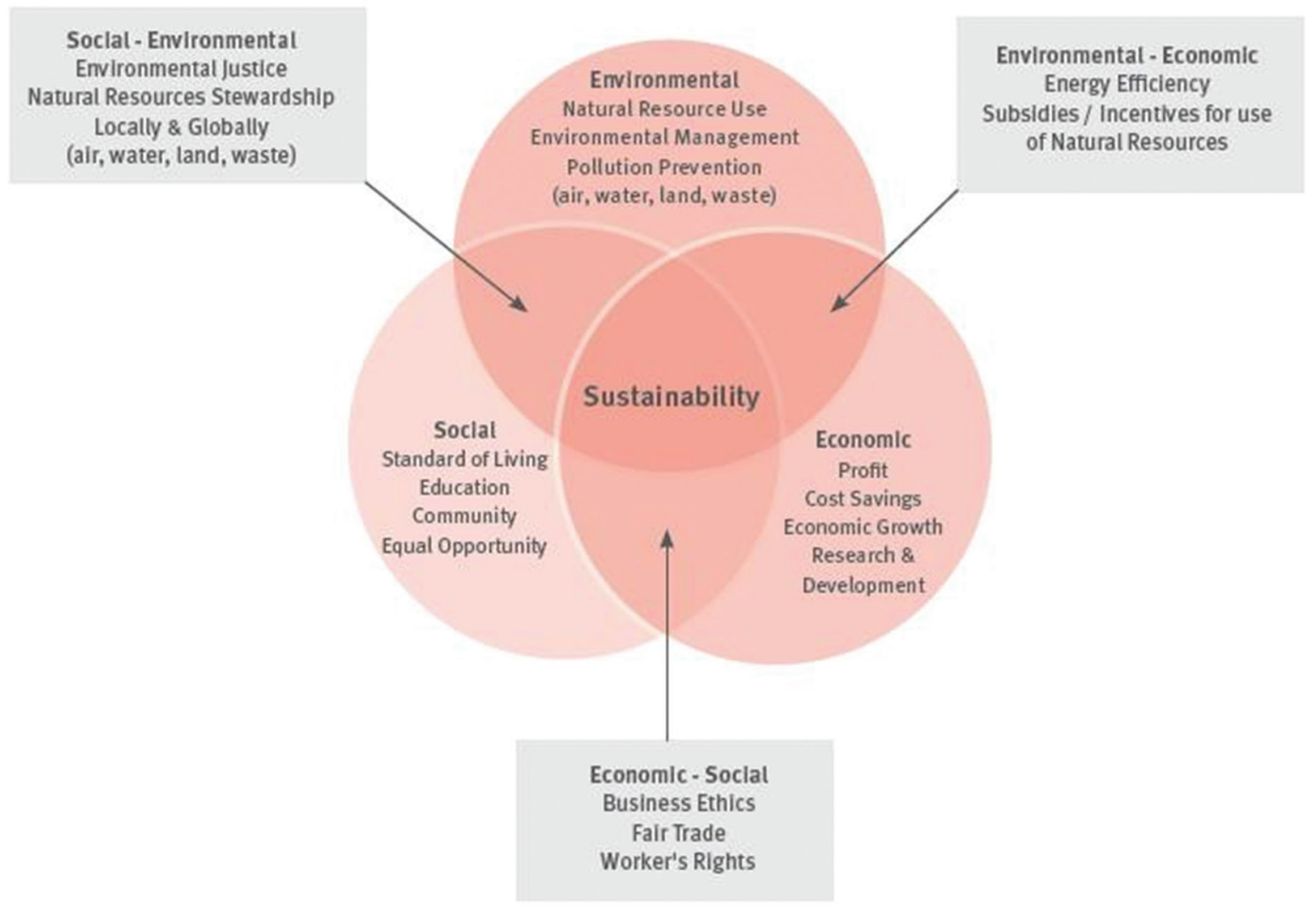

Fig. 5: Aspects of sustainability (Rodriguez et al., 2002). 
only act in its own interests but also in the interests of its stakeholders and the society at large (Sisco et al., 2010).

\subsubsection{The architectural design process}

\subsubsection{Overview and importance}

As one of the key processes in the construction industry, the architectural design process plays a crucial role towards achieving successful delivery of projects. It was meant to be a very critical process as it involves the most important decisions that affect the project performance throughout its life cycle. For instance, end-users participation, cost estimation, material selection and systems and design features are very critical decisions that affect the successful completion of the project positively if well managed or negatively if ignored (Goral, 2007).

\subsubsection{Project life cycle}

Typical project life cycle consists of different phases, each having its own definition, scope of work and participants. According to the Royal Institute of British Architects (RIBA) plan of work updated in 2013, the typical project life cycle is composed of eight stages, namely (1) strategic definition, (2) preparation and brief, (3) concept design, (4) developed design, (5) technical design, (6) construction, (7) handover and closeout and (8) use (RIBA, 2013). This paper will focus on the design stages, namely concept design, developed design and technical design.

\subsubsection{Concept design stage}

This stage focuses on preparing the concept design including outline proposals for structural design, building services systems, outline specifications and preliminary cost information along with relevant project strategies in accordance with design programme. It agrees alterations to brief and issues final project brief. This stage ensures the development of sustainability strategies, the preparation of maintenance and operation plans, handover strategies and risk assessment. It is important to review the project execution plan in order to make sure that every aspect is well implemented and that construction strategies and health and safety issues are clearly stated (RIBA, 2013).

\subsubsection{Developed design stage}

This stage is concerned with preparing developed design, including coordinated and updated proposals for structural design, building services systems, outline specifications, cost information and project strategies in accordance with the design programme. It is no doubt to say that updating sustainability issues, maintenance and operational issues are to be checked permanently in every stage. It is very essential that the change control procedures are implemented to ensure that any change is well controlled. The RIBA plan of work 2013 recommended that this stage may be overlapped with other stages in order to well bind the whole project cycle (RIBA, 2013).

\subsubsection{Technical design stage}

This stage ensures that all the architectural, structural designs and building services information, specialist subcontractor design and specifications are prepared in accordance with the design programme. In addition, during this stage, sustainability aspects are well established as well as maintenance and operational issues and risk assessment are reviewed. The RIBA plan of work 2013 suggests that any change in planning is well addressed in this stage before starting the site works (RIBA, 2013).

\subsection{Challenges of the construction supply chain}

In order to respond effectively to the challenges that the supply chain encounter, these challenges have to be identified and classified. During this research, 20 challenges and their impact on achieving sustainability objectives (i.e. environmental, social and economic) were extracted from literature review and validated by case studies. Table 1 lists the CCSC and indicates whether these challenges were identified from literature, case study or both. Moreover, it shows the effects of the identified challenge on sustainability aspects.

\subsubsection{The rationale behind the CCSS}

The rationale behind the CCSC occurrence is given below by a summary of literature and/or specific case study examples.

\subsubsection{CCSC related to the design and technical process (CCSC 1, 2, 3, 5, 7, 10, 14 and 16)}

Due to its nature, the design process is complex, creative and time-consuming. It aims to develop sustainable solutions that translate the client requirements and end-user needs into technical drawings and specifications (Othman and Abdelwahab, 2016). Failing to deliver the project 
Tab. 1: CCSC

No. Challenges From literature review From case studies

CCSC(1) Delayed design process (Othman et al., 2014;

Subramani et al., 2014).

CCSC (2) Project design cost overrun (Othman and

El-Gendawy, 2010; Baloyi and Bekker, 2011;

Bassioni et al., 2013; Othman and Abdelwahab, 2016).

CCSC (3) Design variations carried out by the architect

(Barrett and Stanley, 1999; Othman et al., 2014; Othman and El-Gendawy, 2010).

CCSC (4) Skills gap of qualified architects and design managers (Richardson 2007; Aring, 2012; Othman and Sokkar, 2019).

CCSC (5) Tight project design schedule (ICE, 1996a,b; Othman et al., 2014; Othman and El-Gendawy, 2010).

CCSC (6) Supplier's rework (Love and Li, 2000; Love and Edwards, 2004).

CCSC (7) Design errors and omissions (Building Research Establishment, 1981; The National Economic Development Office, 1987).

CCSC (8) Failure to abide to contracts requirements (Othman and Harinarain, 2009).

CCSC (9) Inappropriate materials' specifications (Lawson et al., 2014).

CCSC (10) Design changes by the client and other stakeholders at later stages (CIC, 1994; Kubal, 1994; O’Brien, 1998; Veenendaal, 1998; Barrett and Stanley, 1999; Othman et al., 2014).

CCSC (11) Uncoordinated and incorrect construction documents (Wantanakorn et al., 1999; Othman et al., 2014).

CCSC (12) Lack of adhering to environmental requirements and regulations (Othman and Nadim, 2010)

CCSC (13) Lack of considering whole project life cycle cost (CIB, 1996; Smith and Wyatt, 1998; Whyte and Scott, 2010).

CCSC (14) Lack of Integration, coordination and trust between architects and suppliers (Othman et al., 2014; Katunzi, 2011).

CCSC (15) Specifying outdated construction materials and technology (Akadiri et al., 2012).

CCSC (16) Project design complexity (Caniato and Größler, 2015).

CCSC(17) Lack of long-term relationship with involved parties (Thunberg et al., 2017).

CCSC (18) Improper communication and coordination between public authorities and ADFs (O'Leary, 1992; Othman et al., 2014)

CCSC (19) Lack of information flow between architects and suppliers (Craig and Sommerville, 2006; Marquez, 2010).

CCSC (20) Non-compliance to building codes, regulations, laws and standards (Ching and Winkel, 2016). 
design within the agreed timeframe and estimated cost represents one of crucial issues in the construction industry. This could be referred back to a number of reasons including poor scope definition, lack of understating the client business case, slow decision-making process, lack of information provision, inadequate design and insufficient resources and tight schedule to develop appropriate design (ICE, 1996a,b; Othman et al., 2014; Bassioni et al., 2013). Design delay and cost overrun as well as design changes carried out by the architect and other stakeholders at later stages (CIC, 1994; Kubal, 1994; O’Brien, 1998; Veenendaal, 1998; Barrett and Stanley, 1999; Othman and El-Gendawy, 2010) affect the achievement of sustainability objectives in terms of reducing the value delivered to the client, frustrating design team, preventing the client from launching the project on the defined date that reduces the project feasibility and profitability. In addition, these challenges will increase client dissatisfaction and create disputes and litigation between project stakeholders (Baloyi and Bekker, 2011; Subramani et al., 2014). Moreover, lack of integrating and consulting contractors, suppliers and other parties of the CSC during the design process leads to increasing generated waste and design rework (Katunzi, 2011). Other challenges that affect the CSC during the design phase include the project design complexity, which is defined as the characteristics and number of components, technologies and materials that a project contains. Complex design affects the types of problems that the supply chain can encounter such as the number and calibre of suppliers, advanced materials and technologies required. Design complexity has an impact on increasing project duration and cost (Caniato and Größler, 2015). Design complexity and design errors and omissions can have a negative effect on achieving sustainability objectives at social, economic and environmental levels (Building Research Establishment, 1981; The National Economic Development Office, 1987). A case study of 35 residential buildings constructed in the United Arab Emirates confirmed many of the CCSC during the design process. The estimated cost of the project was dirhams (DHS) 53,760,000 and the construction period was 24 months. The later delivery of project requirements, lack of information for items such as soil nature and electricity loads resulted in changing the structural design system and the electricity connection cable to suit the project size. These changes delayed the project handover for 180 days. Moreover, lack of considering environmental requirements resulted in design changes to suit the area weather and shift the water tanks from exposed to underground to protect them from heat and sand storming. As a result, the project cost increased by DHS 5,692,813 and duration by 255 days. Another case is of a building that was initially designed as residential building and then the client decided to change the design suitable for medical centre because of the business offer to lease the building for 20 years. These changes resulted in 100 extra days and additional cost of DHS 298,908 for redesign and approvals. A further 180 days were required to find a funding body to finance the extra DHS 2,104,318 for hospital equipment (Othman et al., 2014).

\subsubsection{CCSC related to coordination, information flow and accuracy (CCSC 11, 17, 18 and 19)}

The successful delivery of the project design entails effective coordination, communication and long-term relationship between the project participants during the design phase. In addition, information flow and accuracy plays a prominent role in facilitating the design and construction process. Wantanakorn et al. (1999) stated that uncoordinated and incorrect construction documents are a result of many causes such as the fragmentation of the design activities, unfamiliarity of the design team with the project type, time pressure, lack of information flow and over staffing. According to Othman et al. (2014), contradiction between construction documents affects the sustainable delivery of projects in terms of conflicts between participants, time, cost and effort needed to rectify and resolve the inconsistency between different construction documents. In addition, lack of communication and coordination between public authorities and ADFs has a number of impacts on the sustainable delivery of construction projects such as lack of regulatory update and changing government regulation and codes (O'Leary, 1992). Katunzi (2011) and Thunberg et al. (2017) highlighted the role of integrating and maintaining long-term relationships between the design team and supply chain parties in delivering sustainable design projects by creating conducive business environment that encourages creativity, trust and collaboration. Marquez (2010) emphasised the role of information flow between the designer and the supplier. These information include material specifications, technical drawings, manufacturing manuals, production schedules, client requirements and inventory information. However, architects take time to share information and do not share project information early in the design phases. These actions increase information lead-time by making the flow of information stagnate at some points of the supply chain in the construction phase (Craig and Sommerville, 2006). A New Shopping and Retail Space 
Centre case study in the UK confirmed many of these challenges. The nature and complexity of the project implied the involvement of suppliers and subcontractors from widely distributed geographic areas. Thus maintaining effective communication between the project participants is a vital process for the design development. The remote locations of supply chain members affected the collaboration and information flow during the design process. In addition, the poor communication impacted also on the project cost and time as many conflicts arose and incomplete and inaccurate designs were addressed during the construction phase (Xie et al., 2010).

\subsubsection{CCSC related to material specification, technology, supplier rework and whole life cycle cost (CCSC 6, 9, 13 and 15)}

The CSC professionals recognise that rework is a significant factor contributing to poor project performance. Love and Li (2000) defined rework as doing something at least one extra time due to non-conformance to requirements. Essentially, rework which accounts for $79 \%$ of total cost deviation is a result of errors, omissions, failures, damages and change orders that affect the CSC performance (Love and Edwards, 2004). Suppliers rework has a negative impact on sustainability in terms of generating waste, increasing cost and double effort of workers. In the same context, the proactive involvement of suppliers in the development and procurement phases of materials, equipment and systems specifications and standardisation will aid in reducing the whole life cycle cost, negative environmental impacts and enhancing project performance (Lawson et al., 2014). This is because suppliers have the experiences of material specifications, workability, maintainability, availability, time of purchasing, importing and manufacturing. It is estimated that $75-85 \%$ of avoidable total cost are controllable at the schematic design stage. Moreover, rapid improvement of construction materials and technology coupled with the lack of designer's experience to follow-up these improvements and excluding suppliers from the design process resulted in specifying outdated materials and technology which were no longer produced or available in market. This affects the sustainability of the delivered project due to the delay, cost and effort required to change the specified materials and technology to match market availability (CIB, 1996; Akadiri et al., 2012; Whyte and Scott, 2010). Two residential housing projects in Amman, Jordan, confirmed these challenges. Inappropriate specification and inaccurate calculation of material amount during the design phase as well as lack of material delivery played a major role in increasing the project duration, cost, waste and client dissatisfaction. This project was delayed by $50 \%$ of its duration (Al-Werikat, 2017). Another example is the Lansing Community College (LCC), Michigan, USA. The cost of the new campus building exceeded the allocated budget. Therefore, LCC decided to redesign the project or scrap part of it. The building was originally designed as a three-story building with a future fourth floor expansion. The expansion exceeded the $\$ 2.5$ million budget for steel fabrication and erection by $\$ 200,000$. The involvement of Ruby and Associates Consulting Structural Engineers and Douglas Steel Fabrication Corporation helped developing sustainable project through redesigning the project and succeeded to eliminate 700 steel members and 1,400 connections, while shear studs were reduced by 11,000. Overall, approximately 300 tons of steel were saved. This saved enough money to enable LCC to construct the fourth floor upfront while bringing the project in approximately $\$ 100,000$ under budget and on schedule. In addition, using information technology in communication and exchange of files and information reduced the redesign time and enhanced communication between different parties. The new design maintained design intent and made the project easier to build (Aeck and Ruby 2006).

\subsubsection{CCSC related to skills gap of qualified architects and design managers and non-compliance to building contracts, codes, regulations, laws and standards (CCSC 4, 8, 12 and 20)}

Skills gap is one of the pressing problems that encounter the construction industry. It is either (1) skills shortage that appears when there are not enough people with skills to meet the demand of the industry or (2) skills mismatch that occurs when the employees have skills and do not meet the industry needs and agree to work under any condition (Richardson 2007; Othman and Sokkar, 2019). Skills gap of qualified architects and design managers is an obstacle to growth, innovation and delivering sustainable services and products. Closing the skills gap has a direct connection with improving productivity, human development and economic growth (Aring, 2012). In addition, contracts are tools designed to organise the relationship between different project participants and reduce the potential risks that may lead to project failure. Failing to adhere to carry out the work in accordance with contracts requirements will lead to unsustainable delivery of projects due to disputes, time delay, cost overrun, poor quality, environmental non-compliance and client dissatisfaction (Othman and Harinarain, 2009). Moreover, adhering to 
environmental requirements and regulations during the design process is an essential and integral part of delivering sustainable projects. Failing to consult supply chain professionals to consider environmental requirements and regulations will impact negatively on the sustainability of the delivered design due to the generation of waste and toxic materials, increasing green gas emission effluent that are harmful to human health (Othman and Nadim, 2010). Furthermore, project design must adhere to regulations and codes that are developed to protect public health, safety and general welfare as they relate to the construction and occupancy of buildings and structures. The building codes became law of a particular jurisdiction when formally enacted by the appropriate governmental or private authority (Ching and Winkel, 2016). Non-compliance to building codes, regulations, laws and standards affect the sustainability of the delivered project socially, economically and environmentally. A case study of Hyatt Regency Kansas City, Kansas City, Missouri, confirmed these challenges. In 1981, the upper walkway fell on the lower walkway, and the two fell onto the crowded dance floor, killing 114 people and injuring over 200 . The two walkways were supported above one another and suspended from the ceiling by hanger rods. The walkways were supported on box beams, which were made of two steel channels, welded together. In the original design, a single rod supported the two walkways as shown in Figure 6. The originally designed hanger detail for the two walkways was altered at the time of fabrication by the supplier. The designer did not check the changes made by the supplier. In addition, the designer did not communicate or called for a meeting with the steel supplier to further understand the changes of design. Finally, the designer agreed upon the requested changes without inspection or checking the calculations, which resulted in this vital error (Marshall et al., 1982).

\section{Data analysis}

This section presents and analyses the results of a survey questionnaire conducted with a representative sample of ADFs in Egypt to quantity the identified CCSC and investigate the perception and application of achievement of sustainability objectives by overcoming the CCSC during the design process. Two approaches were applied to analyse collected data. First, the measure of central tendency is used to get an overview of the typical values for each variable through computing the mean, median and mode. The measure of dispersion is used to investigate the homogenous or heterogeneous nature of the collected data by calculating the variance (V) and the standard deviation (SD) (Bernard 2000). Analysis of the collected data revealed close values of these measures, which confirmed its quality and homogeneity. Second, because not all challenges have the same importance for achieving sustainability, the relative importance index (RII) was used to differentiate between these challenges using the formula $\mathrm{RII}=(\Sigma \mathrm{W} / \mathrm{AN}$, where $\mathrm{W}=$ weighting given to each challenge by the respondents on a Likert scale from 1 to $5, A=$ highest weight ( 5 in our case) and $\mathrm{N}=$ total number of samples (Olomolaiye et al., 1987; Shash, 1993; Kometa and Olomolaiye, 1997). Data was analysed with the aid of Microsoft Excel spreadsheet. Since there is no quantification without qualification

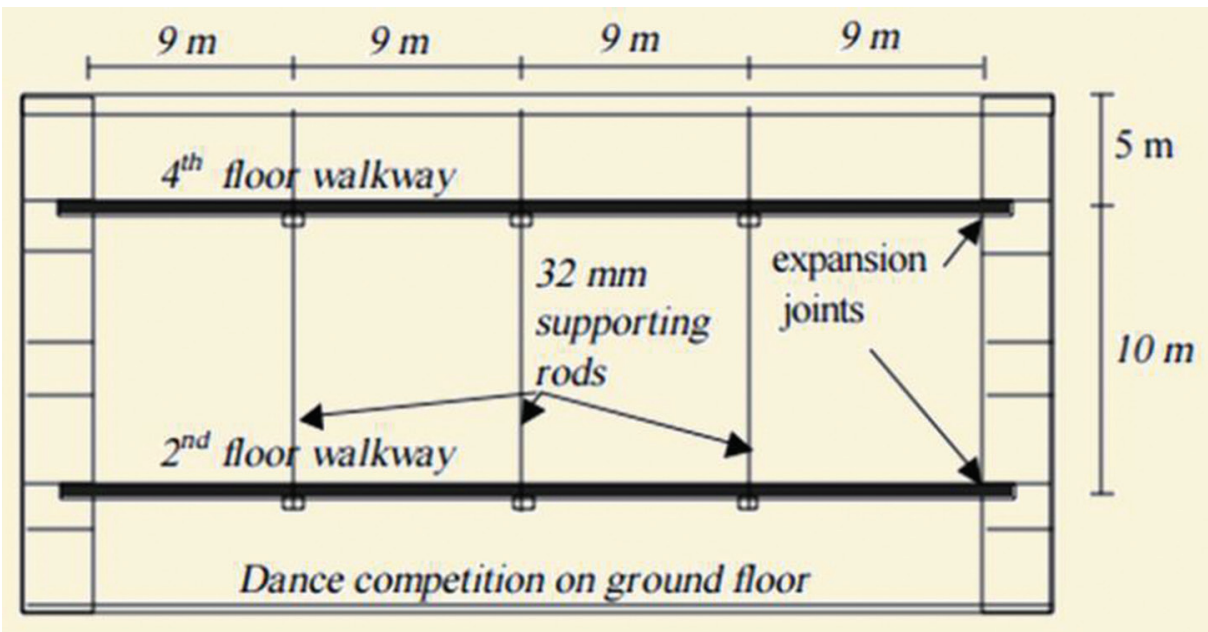

Fig. 6: The two walkways (Marshall et al., 1982). 
and no statistical analysis without interpretation (Bauer and Gaskell, 2000) during the course of this research, both approaches of quantitative and qualitative data analysis were employed.

\subsection{Questionnaire survey sample}

The sampling plan using a random probability sampling method was applied to the population size, which was 44 ADFs registered in the Egyptian Engineers Syndicate (EES, 2018). This allowed every unit an equal chance of being included in the sample (Hannagan, 1986; De Vaus, 1990). This helped selecting a representative and unbiased sample. In order to calculate the sample size, the next two equations were used (FluidSurveys Team, 2014).

In this research, the confidence level chosen is 95\% and the margin of error is 5\%. The confidence level score corresponding to the confidence level of $95 \%$ is 1.96 .

However, as the true sample size is only different from the population size by 4 , the population size would be considered entirely for the survey questionnaire.

\subsection{Response rate and respondents' profile}

Out of 44 ADFs, only 31 firms responded to the survey questionnaire, which represents $70.4 \%$. The number of years of experience of these firms in the construction industry ranges from 5 to 50 years. They are involved in all types of projects including residential, commercial, medical, industrial, cultural, business, recreational and educational. The size of these firms ranges from 10 to 50 employees with architecture, engineering and constructions backgrounds.

\subsection{Results}

\subsubsection{Awareness and influencers of supply chain in the Egyptian construction industry}

A total of $63.33 \%$ of respondents mentioned that they are aware of the concept of CSC. Respondents' rated on a scale of $1-5$, the influence that the different parties of the supply chain can play towards achieving sustainability in construction projects as follows: architect (37\%), contractor (29\%), client (22\%), project manager (17\%) and suppliers (13\%) (see Figure 7). The high rank of architects as an important party to influence the achievement of sustainability is due to their role in providing the design with sustainable features, materials and systems. While respondents rated suppliers as the lowest influential party due to the nature of the traditional procurement approach that separates the design team from the construction and supply team (Azhar et al., 2014).

\subsubsection{Ranking and relative importance of construction supply chain challenges}

Table 2 shows the measure of central tendency and dispersion of all challenges that affect the CSC towards achieving sustainability during the design phase identified from literature review on a scale of $1-5$ (where $1=$ least important and $5=$ highest important). To further investigate

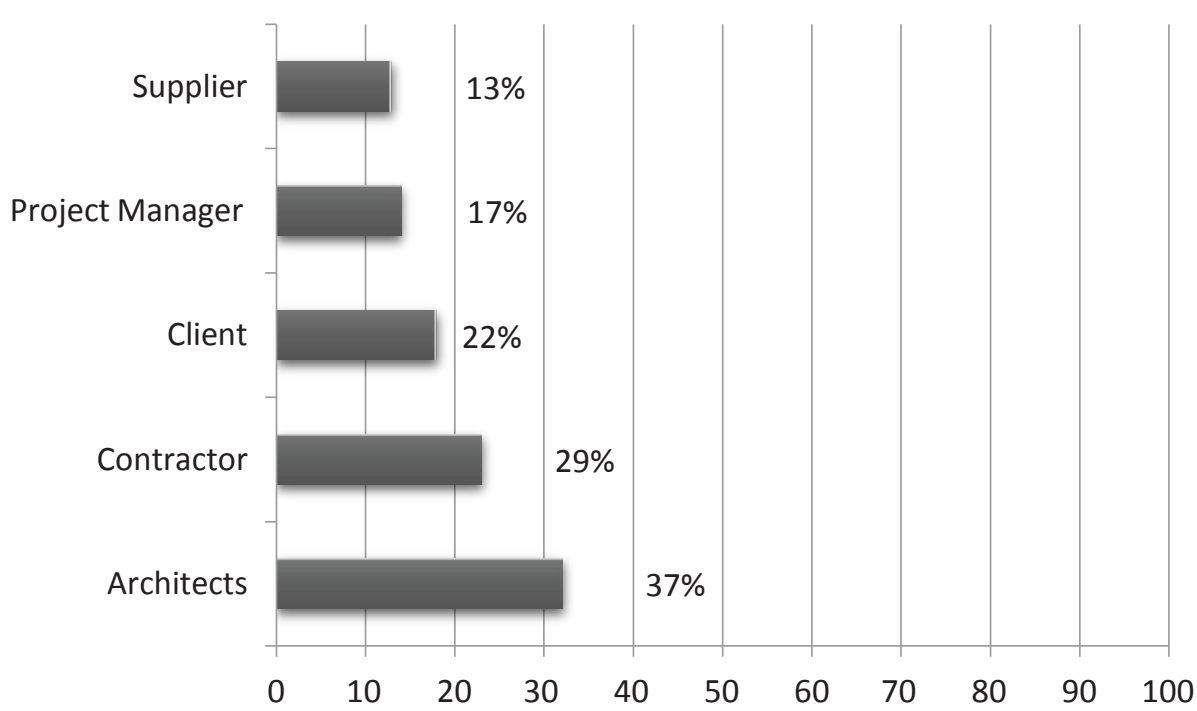

Fig. 7: Influence of supply chain on achieving sustainability in construction projects. 
Tab. 2: CCSC against their measures of central tendency, dispersion and ranking.

\begin{tabular}{|c|c|c|c|c|c|c|c|c|c|c|c|c|}
\hline No. & $\begin{array}{l}\text { Challenges of the construction } \\
\text { supply chain (CCSC) }\end{array}$ & Mean & Median & Mode & $\mathbf{v}$ & SD & Percen & $\begin{array}{r}\text { age of res } \\
\text { scoring }\end{array}$ & ondents & RII & Rank & Final rank \\
\hline (1) & (2) & (3) & (4) & (5) & (6) & (7) & $<3(8)$ & $3-4(9)$ & $>4(10)$ & (11) & (12) & (13) \\
\hline $\operatorname{ccsc}(1)$ & Delayed design process & 4.90 & 5 & 5 & 0.78 & 0.88 & 0 & 3 & 28 & 0.98 & (1) & 1 \\
\hline $\operatorname{ccsc}(2)$ & Project design cost overrun & 4.81 & 5 & 5 & 0.75 & 0.86 & 0 & 5 & 26 & 0.96 & (2) & 2 \\
\hline $\operatorname{ccsc}(3)$ & $\begin{array}{l}\text { Design variations carried out by } \\
\text { the architect }\end{array}$ & 4.71 & 5 & 5 & 0.72 & 0.85 & 1 & 5 & 25 & 0.94 & (3) & 3 \\
\hline $\operatorname{ccsc}(4)$ & $\begin{array}{l}\text { Skills gap of qualified architects } \\
\text { and design managers }\end{array}$ & 4.65 & 5 & 5 & 0.70 & 0.83 & 1 & 6 & 24 & 0.93 & (4) & 4 \\
\hline $\operatorname{cCSC}(5)$ & Tight project design schedule & 4.55 & 5 & 5 & 0.69 & 0.83 & 1 & 7 & 23 & 0.92 & (5) & 5 \\
\hline $\operatorname{ccsc}(6)$ & Supplier’s rework & 4.52 & 4 & 4 & 0.66 & 0.81 & 2 & 7 & 22 & 0.90 & (6) & 6 \\
\hline $\operatorname{ccsc}(7)$ & Design errors and omissions & 4.42 & 4 & 4 & 0.63 & 0.79 & 0 & 17 & 14 & 0.88 & (7) & 7 \\
\hline $\operatorname{ccsc}(8)$ & $\begin{array}{l}\text { Failure to abide to contracts } \\
\text { requirements }\end{array}$ & 4.32 & 4 & 4 & 0.60 & 0.78 & 0 & 20 & 11 & 0.86 & (8) & 8 \\
\hline $\operatorname{ccsc}(9)$ & $\begin{array}{l}\text { Inappropriate materials } \\
\text { specifications }\end{array}$ & 4.26 & 4 & 4 & 0.58 & 0.76 & 1 & 19 & 11 & 0.85 & (9) & 9 \\
\hline $\operatorname{CCSC}(10)$ & $\begin{array}{l}\text { Design changes by the client } \\
\text { and other stakeholders at later } \\
\text { stages }\end{array}$ & 4.16 & 4 & 4 & 0.56 & 0.75 & 1 & 20 & 10 & 0.83 & (10) & 10 \\
\hline $\operatorname{ccsc}(11)$ & $\begin{array}{l}\text { Uncoordinated and incorrect } \\
\text { construction documents }\end{array}$ & 4 & 4 & 4 & 0.52 & 0.72 & 0 & 23 & 8 & 0.80 & (11) & 11 \\
\hline $\operatorname{CCSC}(12)$ & $\begin{array}{l}\text { Lack of adhering to environ- } \\
\text { mental requirements and } \\
\text { regulations }\end{array}$ & 3.74 & 3 & 3 & 0.45 & 0.67 & 1 & 23 & 7 & 0.75 & (12) & 12 \\
\hline $\operatorname{ccsc}(13)$ & $\begin{array}{l}\text { Lack of considering whole } \\
\text { project life cycle cost }\end{array}$ & 3.68 & 3 & 3 & 0.44 & 0.66 & 2 & 22 & 7 & 0.74 & (13) & 13 \\
\hline $\operatorname{ccsc}(14)$ & $\begin{array}{l}\text { Lack of integration, coordination } \\
\text { and trust between architects } \\
\text { and suppliers }\end{array}$ & 3.55 & 3 & 3 & 0.41 & 0.64 & 4 & 21 & 6 & 0.71 & (14) & 14 \\
\hline $\operatorname{ccsc}(15)$ & $\begin{array}{l}\text { Specifying outdated construc- } \\
\text { tion materials and technology }\end{array}$ & 3.42 & 3 & 3 & 0.38 & 0.61 & 5 & 21 & 5 & 0.68 & (15) & 15 \\
\hline $\operatorname{ccsc}(16)$ & Project design complexity & 3.35 & 3 & 3 & 0.36 & 0.60 & 6 & 20 & 5 & 0.67 & (16) & 16 \\
\hline $\operatorname{ccsc}(17)$ & $\begin{array}{l}\text { Lack of long-term relationship } \\
\text { with involved parties }\end{array}$ & 3.29 & 3 & 3 & 0.35 & 0.59 & 7 & 19 & 5 & 0.66 & (17) & 17 \\
\hline $\operatorname{CCSC}(18)$ & $\begin{array}{l}\text { Improper communication and } \\
\text { coordination between public } \\
\text { authorities and ADFs }\end{array}$ & 3.16 & 3 & 3 & 0.32 & 0.57 & 8 & 19 & 4 & 0.63 & (18) & 18 \\
\hline $\operatorname{CCSC}(19)$ & $\begin{array}{l}\text { Lack of information flow between } \\
\text { architects and suppliers }\end{array}$ & 3.03 & 3 & 3 & 0.30 & 0.54 & 10 & 17 & 4 & 0.61 & (19) & 19 \\
\hline $\operatorname{CCSC}(20)$ & $\begin{array}{l}\text { Non-compliance to building } \\
\text { codes, regulations, laws and } \\
\text { standards }\end{array}$ & 2.90 & 3 & 3 & 0.27 & 0.52 & 11 & 17 & 3 & 0.58 & (20) & 20 \\
\hline
\end{tabular}

the data, an RII was used to rate CCSC according to their importance. As would be expected, while some CCSC were highly rated, others do not (see Figure 8). Inspection of the results showed that CCSC could be classified into three categories:

(1) First, the high to very high importance CCSC with RIIs above 0.800 , which includes:

- Delayed design process

- Project design cost overrun

- Design variations carried out by the architect
- Skills gap of qualified architects and design managers

- Tight project design schedule

- Supplier's rework

- Design errors and omissions

- Failure to abide to contracts requirements

- Inappropriate materials specifications

- Design changes by the client and other stakeholders at later stages

- Uncoordinated and incorrect construction documents 
(2) Second, the average to high importance CCSC with RIIs lying between 0.600 and 0.800 , which includes:

- Lack of adhering to environmental requirements and regulations

- Lack of considering whole project life cycle cost

- Lack of Integration, coordination and trust between architects and suppliers

- Specifying outdated construction materials and technology

- Project design complexity

- Lack of long-term relationship with involved parties

- Improper communication and coordination between public authorities and ADFs

- Lack of information flow between architects and suppliers

(3) Finally, the low to average importance CCSC with RIIs less than 0.600, which includes:

- Non-compliance to building codes, regulations, laws and standards

For example, 'delayed design process' was ranked the highest affecting challenge with mean (4.9/5), median and mode (5/5), V (0.78), SD (0.88) and RII (0.98). These results are in line with literature review because delay in the project design leads to cost overrun, design team frustration and client dissatisfaction. In addition, it will prevent the client from launching the project on the defined date, which will affect the project profitability (Subramani et al., 2014).

Another example is the 'inappropriate material specifications', which was ranked 9th with mean (4.26/5), median and mode (4/5), V (0.58), SD (0.76) and RII (0.85). These results are in line with literature review as lack of integrating suppliers in the design process leads to specify materials that either inappropriate to the project or no longer available in market that results in rework and increases the maintenance and operation costs (Othman et al., 2014). Finally, 'Non-compliance to building codes, regulations, laws and standards' was ranked the lowest affecting challenge with mean (2.9/5) and median and mode (3/5), V (0.27), SD (0.52) and RII (0.58). Despite the necessity of adhering to codes and regulations (Ching and Winkel, 2016), respondents ranked this challenge the lowest and referred it to the ineffective application of building codes, regulations, law and standards as well as being not mandate by authorities managing the building process.

\subsubsection{Construction supply chain solutions}

Figure 9 shows the solutions proposed by literature review (Khan, 2019) to address the challenges of supply chain in the construction industry. Respondents were

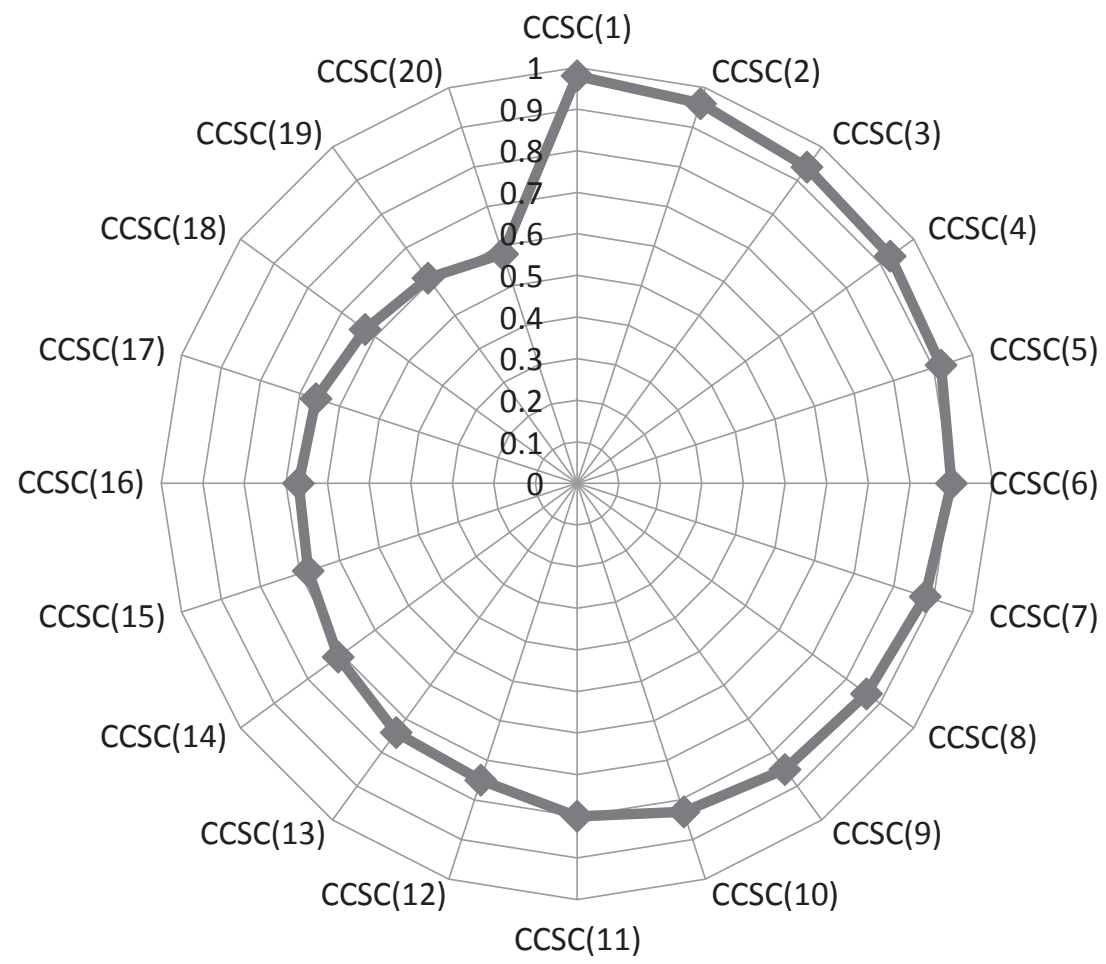

Fig. 8: RII of CCSC. 


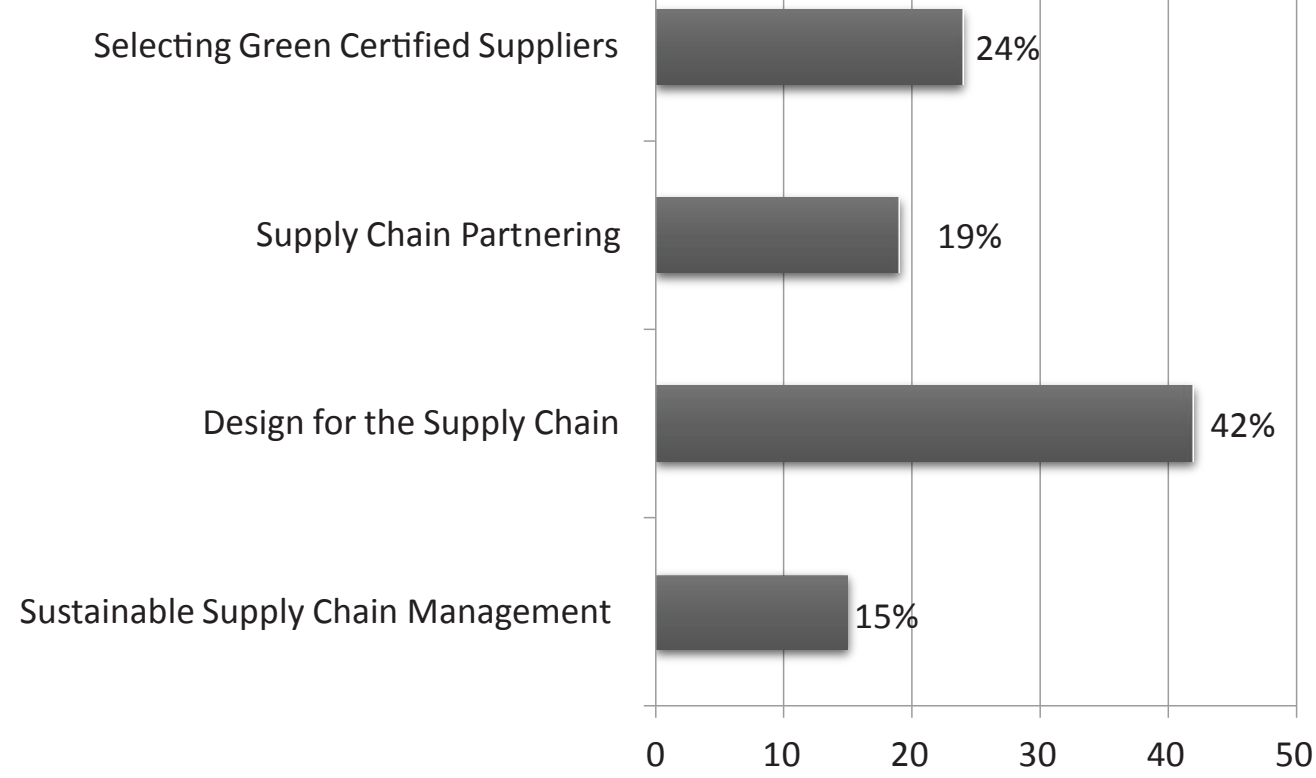

Fig. 9: CSC solutions.

asked to rank these solutions according to their role towards achieving sustainability during the design phase in ADFs in Egypt.

- Around $42 \%$ of respondents selected 'design for the supply chain' because it focuses on how the product of architectural design facilitates the design of supplier's products and CSC process. It compromises modularity in designs for easier manufacturing on site, designing projects for reduced consumption of materials and energy by suppliers, involving suppliers in design phases and selecting local green materials.

- Of the total respondents, $19 \%$ selected 'supply chain partnering', which encourages early supplier involvement in construction projects. This helps increasing efficiency, productivity, relationships, information flow, communication and quality of the production processes in the construction industry.

- Nearly $24 \%$ of respondents chose 'selecting green certified suppliers' because it focuses on cost saving and efficiency beyond traditional techniques by enhancing energy efficiency, quality and environmental performance. In addition, it aims to identify the root causes of waste and inefficiency during the early stages of design.

- About 15\% of respondents selected 'sustainable SCM' as a solution to CCSC. This is because it focuses on managing raw materials and services of suppliers and manufacturers provided to the client. In addition, it encourages information flow across the CSC and project team, establishing trust, communication and integration between project team members.

\section{Construction supply chain management improvement framework}

\subsection{Definition and importance}

A framework is defined as a structure for describing a set of concepts, methods and technologies required to complete a product process and design (EDMS, 2007). The Construction Supply Chain Management Improvement Framework (hereinafter referred to as 'CSCMIF' or 'Framework') is a proposed framework developed by this research to overcome the CCSC as an approach for achieving sustainability in construction projects during the design process. The importance of this framework stems from the necessity to enhance the performance of the CSC towards achieving sustainability objectives in construction projects. In addition, the framework is required to fill the gap in construction literature and establishing organised procedures that enable ADFs to overcome the challenges that affect the construction supply chain. 


\subsection{The aim of the framework}

The CSCMIF is an innovative business improvement tool aimed at overcoming the CCSC towards achieving sustainability in construction projects during the design process.

\subsection{Description of the framework}

The development of the framework is based on the results gained from literature review, case studies and survey questionnaire. It consists of four domains based on the classifications of the CCSC mentioned in Section 3.4 (see Figure 10).

\subsubsection{Design and technical process domain}

The aim of this domain is to overcome the challenges that encounter the CSC related to the Design and Technical Process as an approach for the achievement of sustainability objectives during the design phase. Activities that need to be carried out during this domain are shown in Figure 11.

Achieving the abovementioned activities to attain sustainability objectives necessitates:

- Understating the client requirements and providing the design team and supply chain with needed information in the right form and time will expedite the design decision-making process. Setting plans, deadlines and milestones for the design activities and offering all the resources needed will help meeting targeted objectives and reducing design delay and cost overrun. These activities will help achieving social, economic and environmental aspects of sustainability.

- Integrating the client and supply chain during the design process and allowing proper time for the design team to develop the project design will reduce design changes. In addition, conducting quality planning, assurance and control procedures during design will enable reducing design errors and omissions. These activities will help achieving social and economic aspects of sustainability.

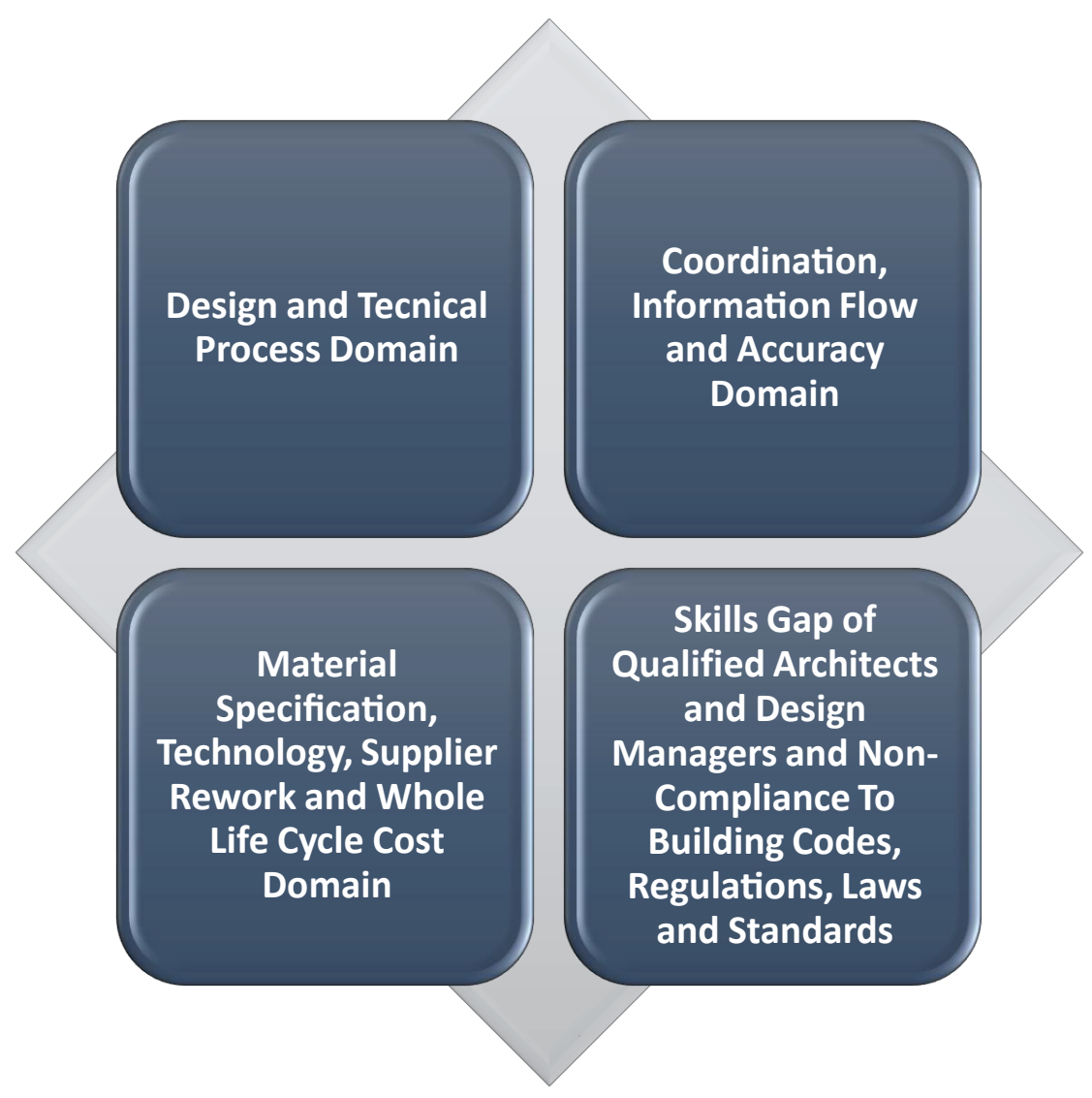

Fig. 10: CSCMIF. 


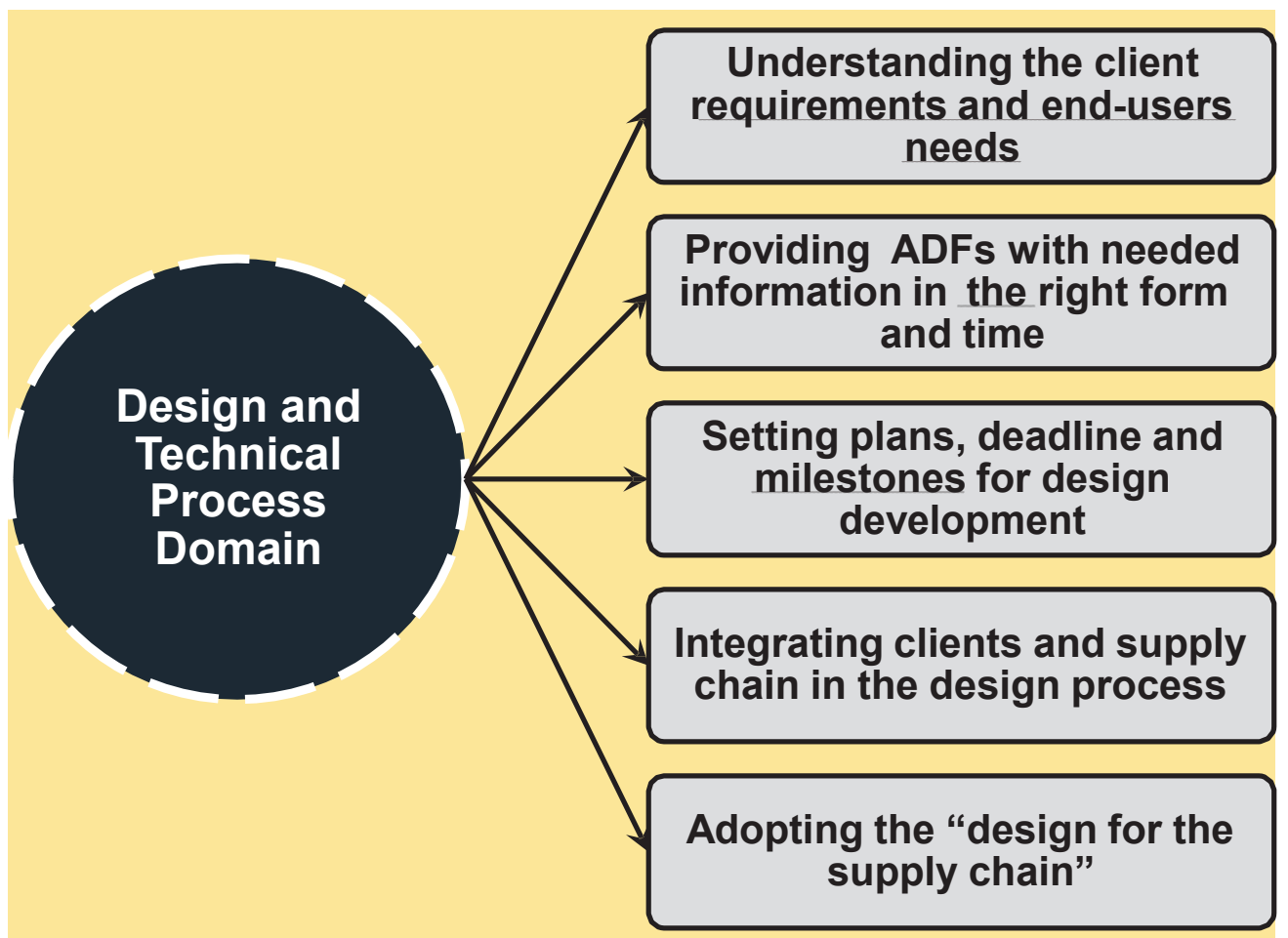

Fig. 11: Activities of the design and technical process domain.

- Adopting the 'design for the supply chain' approach will bring up the client's conceptual thoughts to reality, enhance efficiency, and reduce waste and cost. Furthermore, using modularisation and preassembly design should be considered before actual designing to facilitate the supply chain process such as fabrication, transportation and installation. These activities will help in achieving economic and environmental aspects of sustainability.

\subsubsection{Coordination, information flow and accuracy domain}

This domain aims to overcome the challenges faced by the CSC related to Coordination, Information Flow and Accuracy as an approach for achieving sustainability during the design phase. Activities that need to be carried out during this domain are shown in Figure 12.

Achieving the abovementioned activities to attain sustainability objectives necessitates:

a) Integrating architects and suppliers during the design process and facilitating information flow will help choosing sustainable materials and technology preferably from local market to reduce the importing time, cost and air pollution produced by transportation vehicles and trucks. Often, local materials are better suited to climatic conditions and support national economy growth. These activities will help achieving economic and environmental aspects of sustainability.

b) Establishing effective coordination and communication channels between architects, suppliers and public authorities during the design phase will help sharing ideas and feedback, which will ensure coordinated and correct documents. In addition, it will help avoiding any delay due to changes in regulation and updates in activities. These activities will help achieving social, economic and environmental aspects of sustainability.

c) Implementing transparency policy, where information is shared between all project participants openly, in order to get advice and provide constructive feedback. This will help building cooperation between supply chains and improve the project sustainability accordingly.

d) Conducting regular meetings with project supply chain members to agree on the objectives and benefits of effective relationship and trust between them. Moreover, generating correspondence, reports and manuals in a clear and concise manner and communicating complex issues clearly and credibly with widely varied supply chain members. 


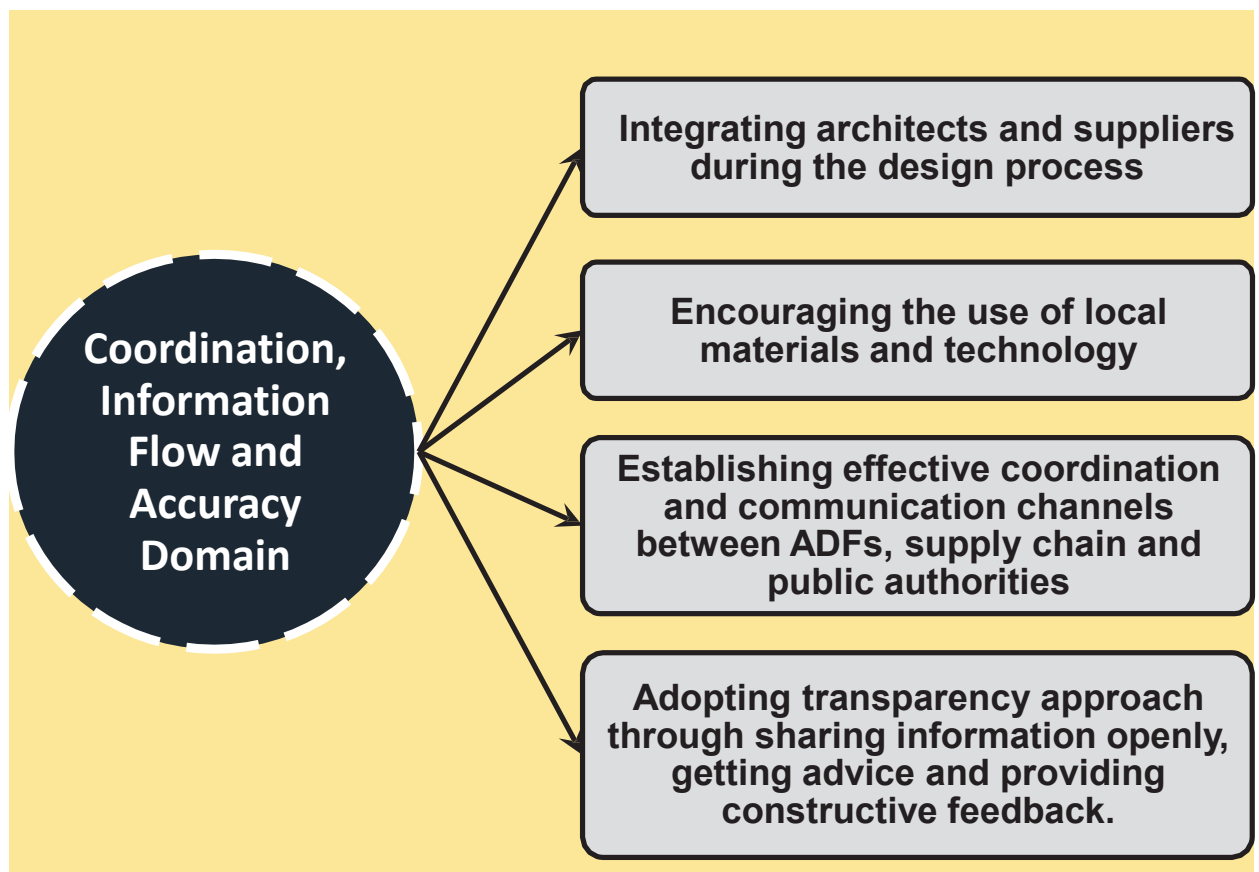

Fig. 12: Activities of the coordination, information flow and accuracy domain.

\subsubsection{Material specification, technology, supplier rework and whole life cycle cost domain}

The aim of this domain is to overcome the challenges that the CSC encounter is related to material specification, technology, supplier rework and whole life cycle cost as an approach for the achievement of sustainability objectives during the design phase. Activities that need to be carried out during this domain are shown in Figure 13.

a) Early supplier involvement in the design process will help achieving sustainability objectives and improving the project performance by proposing alternative designs with substitute materials and systems that provide the required function with minimal cost, reducing supplier's rework, mitigating the difficulties of the logistical issues of getting the products delivered to the site in a timely manner and with minimal impact on the surrounding community. In addition, early supplier involvement will help building longterm relationship and trust between the project participants, introducing new knowledge regarding the properties and applications of newly introduced materials (Chavhan, 2012; Northey, 2018). Suppliers from different disciplines could be integrated in the design process to provide advice to the design team. They could be hired as advisors who deliver a consultancy service based on a contract drafted for this purpose and they could be paid either monthly or on a lump sum basis.

b) Involving supply chain during the selection of appropriate materials and equipment that suit the project life cycle cost will achieve sustainability through reducing the operation and maintenance cost as well as environmental hazards in addition to increasing the project life span and end-user satisfaction.

\subsubsection{Skills gap of qualified architects and design managers and non-compliance to building codes, regulations, laws and standards}

This domain aims to overcome the challenges that the CSC face related to Skills Gap of Qualified Architects and Design Managers and Non-Compliance to Requirements, Regulations and Codes as an approach for achieving sustainability during the design phase. Activities that need to be carried out during this domain are shown in Figure 14.

Achieving the abovementioned activities to attain sustainability objectives necessitates:

a) Enhancing the skills of architects and design managers through training and skills development will help achieving social and economic aspects of sustainability by bridging the skills gap, improving productivity and growth development. 
b) Employing quality management procedures to ensure that contract requirements, environmental regulations and building codes are adhered to during the design process. This will help achieving sustainability through reducing conflicts and reducing the time and cost lost to rectify the documents to meet requirements, regulations and codes.

\subsection{Benefits and limitations of the framework}

The developed framework acts as a business improvement model to achieve sustainability by overcoming the CCSC during the design process. The proposed framework has benefits as it classifies the domains for improvement to include (1) design and technical process, (2) coordination, information flow and accuracy, (3) material specification, technology, supplier rework and whole life cycle cost, and (4) skills gap of qualified architects and design managers and noncompliance to requirements, regulations and codes. Such classification enables ADFs to focus their efforts, provide appropriate training programmes and offer facilities required towards overcoming the CCSC. In addition, it helps raising the awareness of ADFs about the importance of integrating suppliers in the design process. However, the adoption and application of the

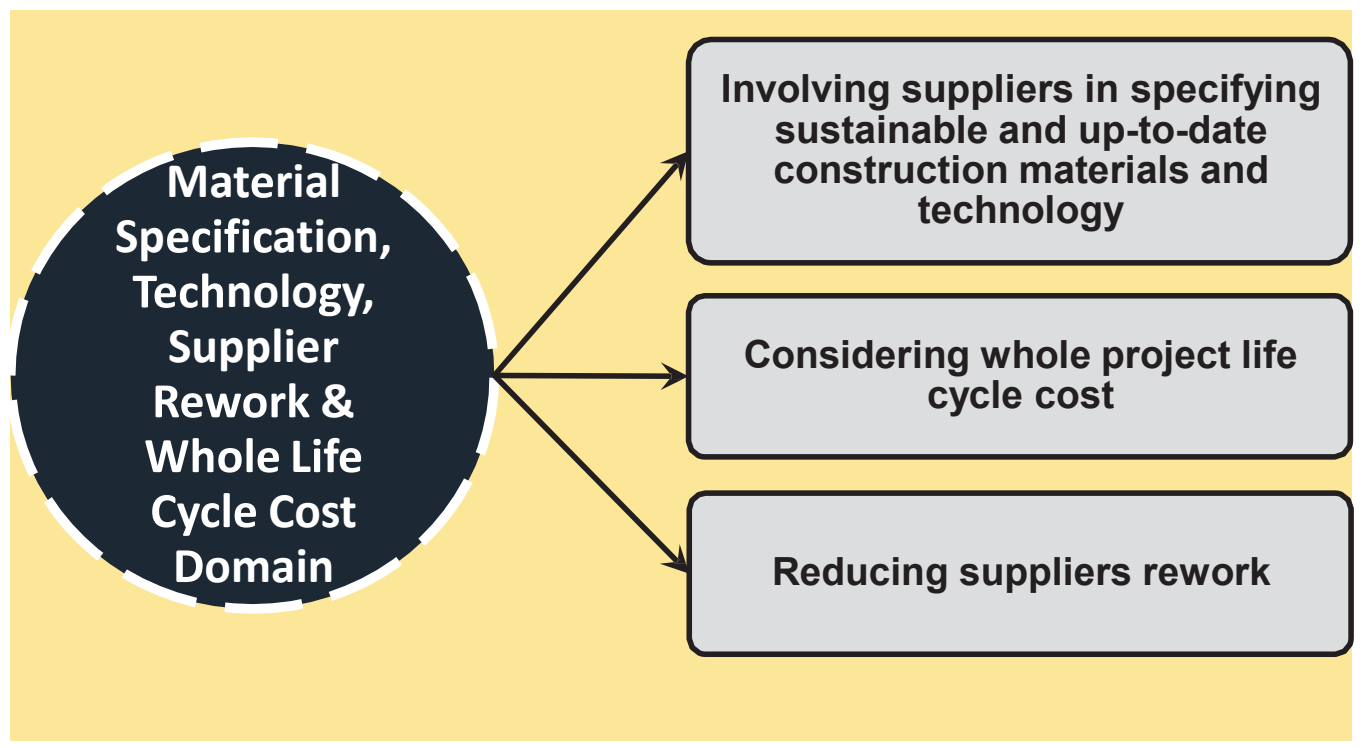

Fig. 13: Activities of the material specification, technology, supplier rework and whole life cycle cost domain.

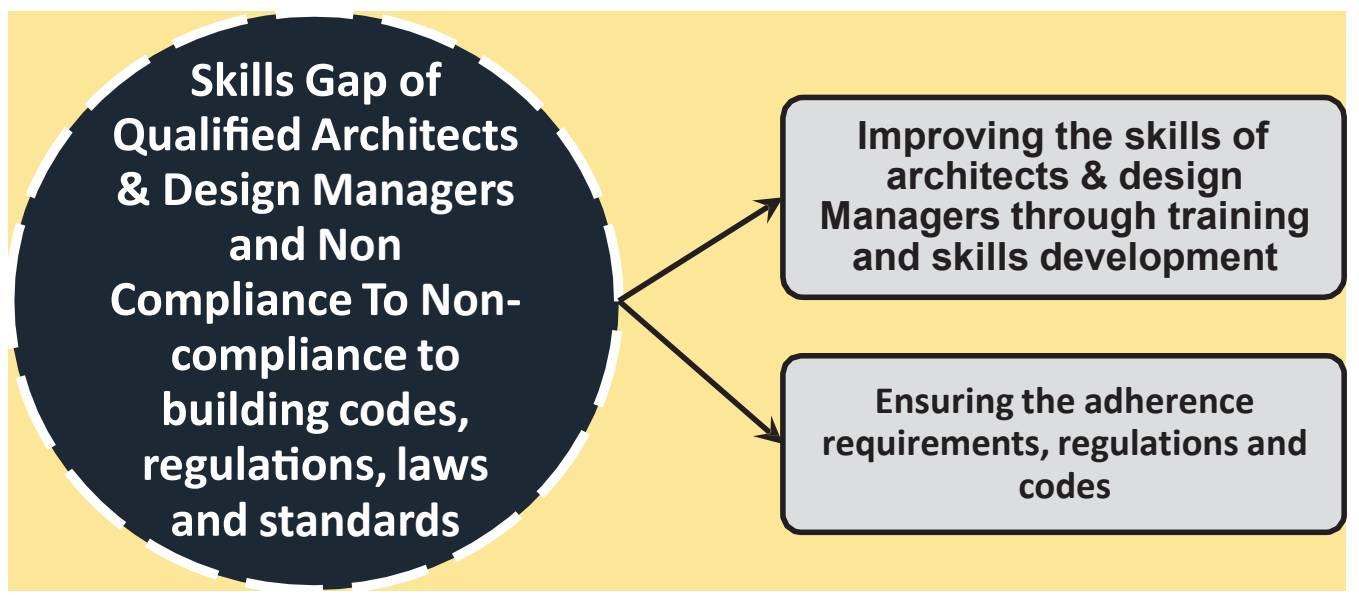

Fig. 14: Activities of the coordination, information flow and accuracy domain. 
proposed framework requires whole organisational commitment and provision of training, raising awareness and facilities to ensure its success. The framework is a time-consuming process that may not be welcomed by a number of ADFs and supply chain members in the construction industry because of time constraints and the reluctance to change. In addition, the success of the framework depends, to a large extent, on the willingness and support of the senior management to adopt and apply the proposed framework. Though the involvement of suppliers in the design process will add to the project cost, the expected benefits of their involvement will help avoiding errors or issues that will cost higher than the fees paid to them.

\subsection{Action plan for implementing the construction supply chain management}

\subsubsection{Improvement of framework}

In order to put the proposed framework in practice, an action plan was developed by the authors. The action plan proposed to implement the framework composed of five functions, namely:

- Identifying the challenge of CSC,

- Establishing the implementation objectives,

- Developing the implementation plans,

- Executing implementation plans, and

- Monitoring and evaluating the implementation plans (see Figure 15).

\subsubsection{Identifying integration problem}

The 'identifying the CCSC' function is an important activity of this action plan because it enables ADFs to identify the core challenges that obstruct the achievement of sustainability objectives in construction projects. It is essential to form an effective team (including a competent team leader) to carry out the implementation study. Achieving a balance between the need for participants who represent various areas of expertise and possess diverse background is fundamental for accomplishing the study objectives. The study team should contain between six and twelve full-time participants to maintain optimum productivity (Norton and McElligott 1995). Performing an early orientation meeting will help in establishing strategic issues such as study duration, resources required and assigning responsibilities to team members. Senior management support will facilitate the provision of needed resources and the adoption of study decisions and recommendations. Data collection methods (i.e. literature review, survey questionnaire, interviews and case studies) and data analysis techniques (i.e. quantitative and qualitative) have to be defined and utilised. Brainstorming techniques, team consensus and evaluation matrix have to be used for identifying the root causes and rank them according to their importance.

\subsubsection{Establishing the implementation objectives}

Towards implementing the proposed framework in ADFs, the objectives of implementing the action plan have to be adequately established and agreed by all participants. This could be achieved using brainstorming techniques and team consensus to generate and select objectives that address the identified challenges. Establishing implementation objectives gives team members ownership to these objectives and encourages the study team to accomplish them. Evaluation matrix will be used to rank these objectives based on their significance. In addition, this function will also result in defining the criteria to be used to measure the achievement of sustainability objectives in ADFs during the design phase.

\subsubsection{Developing implementation plans}

The 'developing implementation plans' function aims to set the procedures and actions necessary to accomplish the implementation objectives. It will include a work breakdown structure and a responsibility matrix, where the first downsizes the work into manageable work packages and the later links the activity to be done to the responsible person. In addition, the plans should include expected risks and corrective actions to be taken in case of the plan did not go as intended. Furthermore, the communication plan between the study team has to be developed to portray the reporting structure during overcoming the CCSC in the design phase.

\subsubsection{Executing implementation plans}

Within this function, the plans developed in the previous function will be executed. The execution plans may require that employees involved in the implementation process be trained and equipped with all tools and technologies required to guarantee the successful execution 


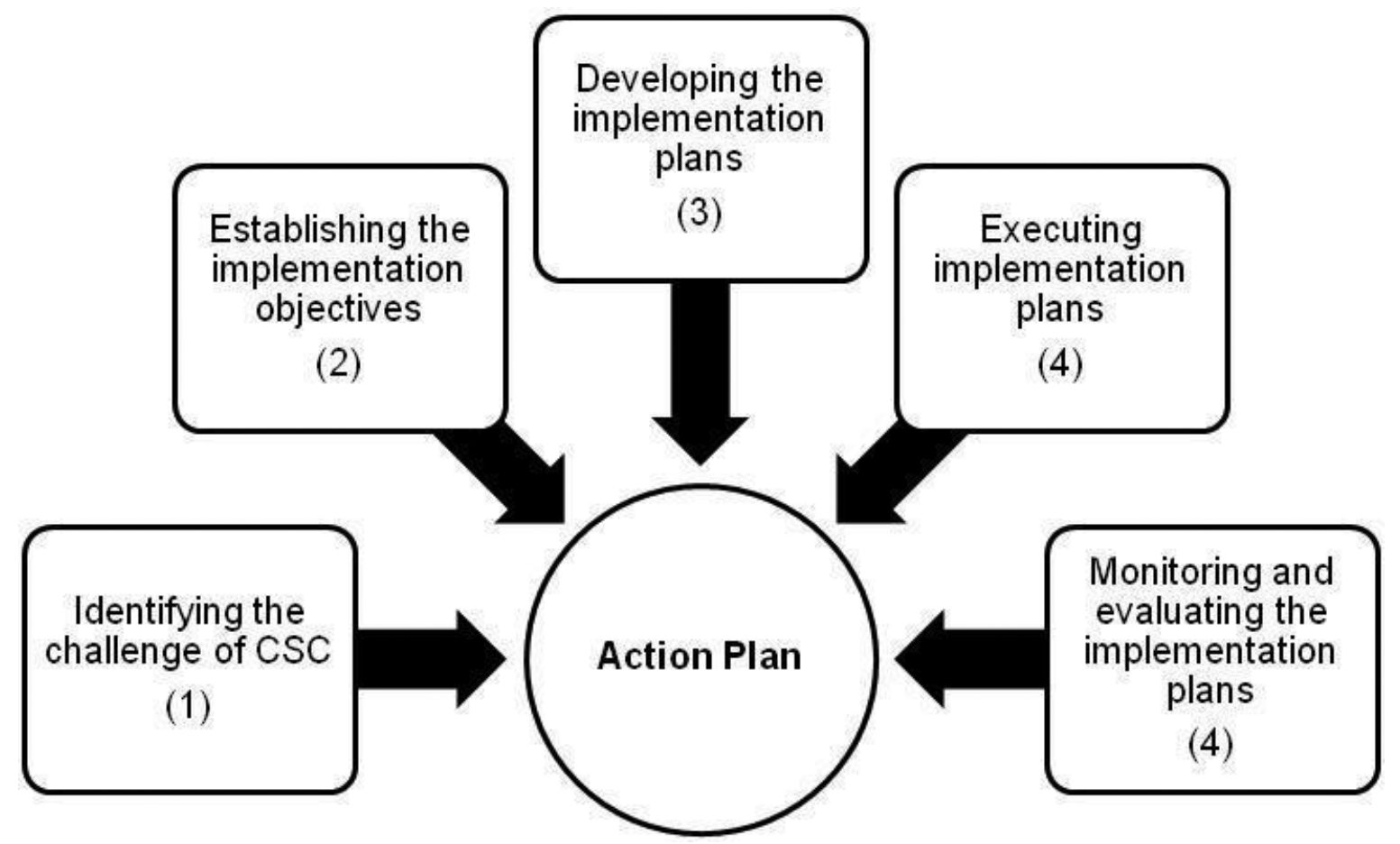

Fig. 15: Functions of the action plan (developed by the authors).

of plans. In addition, the support of senior management and its offering the required facilities will help achieving the implementation objectives. The execution function should use the work authorisation system, which verifies the predecessor activities and permits the successor activities to proceed. This ensures the quality of work performed.

\subsubsection{Monitoring and evaluating the implementation plans}

The aim of this function is to ensure that overcoming CSCC towards achieving sustainability objectives during the design phases goes according to the plans. Comments and feedback from the execution team will enable taking corrective actions if plans were not implemented as contrived. Furthermore, this will help improving the performance of ADFs in future projects.

\section{Conclusion and recommendations}

Being one of the biggest industries worldwide, the construction industry contributes towards achieving the social and economic development objectives of countries worldwide. At the social level, it provides communities with buildings and facilities that meet their needs and fulfil their requirements. At the economic level, it provides most of the countries' fixed capital assets, increases GDP, offers job opportunities and supports other industrial sectors to excel. Conversely, the construction industry has a major impact on the environment in terms of waste and pollution generation, energy consumption and water contamination, which calls for the construction industry to be more sustainable. Construction projects are usually delivered through a supply chain network consists of all parties involved in the project development process. Despite the valuable role of the CSC, it has been argued that its performance needs to be improved in order to achieve sustainability objectives. During the course of this research, 20 challenges that encounter the CSC and affect achieving sustainability were identified, classified and validated through literature review and case studies. In addition, a survey questionnaire was conducted with a representative sample of ADFs to quantify the CCSC and investigate the perception of ADFs towards achieving sustainability through overcoming these challenges. Based on the above, the research developed an innovative business improvement framework to enhancing the performance of the CSC towards achieving sustainability during the design process. In addition, an action plan was developed to explain how the proposed framework could be 
implemented in practice. Accordingly, the research comes up with the following recommendations to ADFs.

1) Raising the awareness of all parties involved in the construction project about the important role played by the CSC towards achieving sustainability objectives during the design phase.

2) Providing necessary training and resources to enhance the design and technical skills of architects and design managers to facilitate information flow, expedite the decision-making process, conduct quality assurance and control.

3) Fostering coordination, integration, communication and information flow between ADFs and supply chain to help specifying appropriate materials and equipment, understanding the client requirements and end-users needs as well as life cycle considerations.

4) Encouraging trust and relationship between ADFs and supply chain to help sharing information, providing feedback and advice, and facilitating communication of complex issues.

5) Engaging employees in developing their firms' visions, missions and strategies to include the collaboration and integration with different CSC networks.

6) Providing the senior management of ADFs with successful examples of the role of supply chain towards achieving sustainability will help providing the needed resources and allowing ample time for implementation to ensure successful results.

7) Issuing laws to encourage collaboration between ADFs and supply chain networks and enforcing laws for green building design.

8) Conducting the same study to investigate the role collaboration between other construction professionals (e.g. structural engineers, quantity surveyors) and suppliers towards achieving sustainability in construction projects.

\section{References}

Abdellatif, M. A., \& Othman, A. A. E. (2006). Improving the sustainability of low-income housing projects: The case of residential buildings in Musaffah Commercial City in Abu Dhabi. Emirates Journal for Engineering Research, 11(2), pp. 47-58.

Addis, B., \& Talbot, R. (2001). Sustainable construction procurement: A guide to delivering environmentally responsible projects. CIRIA C571, London, CIRIA.

Aeck, R. C., \& Ruby, D. I. (2006). “Consider constructability”, modern steel construction. [Online]. Available at https:// www.rubyandassociates.com/user_area/content_media/ raw/2006v04_consider_constructability_m(1)m.pdf [accessed 23 November, 2019].

Akadiri, P. O., Chinyio, E. A., \& Olomolaiye, P. O. (2012). Design of a sustainable building: A conceptual framework for implementing sustainability in the building sector. Buildings, 2, pp. 126-152.

AlNassar, N., Othman, A. A. E., \& Elsaay, H. (2018). Investigating the architect's role towards enhancing the sustainability of the construction supply chain in developing countries. In: Proceedings of the Green Heritage: Chance - Change Challenge, the British University In Egypt, Cairo, 6-8 March 2018, pp. 82-114, ISBN:978-977-490-500-1.

Al-Werikat, G. (2017). Supply chain management in construction. International Journal of Scientific \& Technology Research, 6(3), pp. 106-110.

Anink, D., Boodtra, C., \& Mark, J. (1996). Handbook of sustainable development. James and James, London.

Arbulu, R. J., \& Tommelein, I. D. (2002). Alternative supply-chain configurations for engineered or catalogued made-to-order components: case study on pipe supports used in power plants. Proceedings IGLC-10, Aug. 2002, Gramado, Brazil.

Aring, M. (2012). Skills gaps throughout the world: An analysis for UNESCO. Global Monitoring, Report 2012. Available at http://unesdoc.unesco.org/images/0021/002178/217874e.pdf [accessed 15 September, 2018].

Azhar, N., Kang, Y., \& Ahmad, I. U. (2014). Factors influencing integrated project delivery in publicly owned construction projects: An information modelling perspective. Procedia Engineering, 77, pp. 213-221.

Baker, T. L. (1994). Doing Social Research, 2nd edn. McGraw-Hill, New York, NY.

Baloyi, L., \& Bekker, M. (2011). Causes of construction cost and time overruns: The 2010 FIFA world cup stadia in South Africa. Acta Structilia, 18(1), pp. 51-67.

Barrett, P. S., \& Stanley, C. (1999). Better Construction Briefing. Blackwell Science Ltd, Oxford.

Bassioni, H. A., Sarhan, A., \& Zaki, A. S. (2013). Cost overrun causes related to the design phase in the Egyptian construction industry. Journal of Engineering Management Research, 1(5), pp. 138-147.

Bernard, H. R. (2000). Social Research Methods: Qualitative and Quantitative Approaches. Sage Publishing Ltd, London.

Bowen, P. A., Pearl, R. G., \& Edwards, P. J. (1999). Client briefing process and procurement method selection: A South African study. Engineering, Construction and Architectural Management, 6(2), pp. 91-104.

Boyko, C. T., Cooper, R., Davey, C. L., \& Wootton, A. B. (2006). Addressing sustainability early in the urban design process. International Journal of Management of Environmental Quality, 17(6), pp. 689-706.

Broft, R., Badi, S., and Pryke, S. (2016). Towards supply chain maturity in construction. Built Environment Project and Asset Management, 6(2), pp. 187-204.

Building Research Establishment. (1981). Quality Control on Building Sites. Garston London, UK.

Caniato, F., \& Größler, A. (2015). The moderating effect of product complexity on new product development and supply chain management integration. Production Planning \& Control, 26(16), pp. 1306-1317. 
Chavhan, R. (2012). Supplier development: Theories and practices. IOSR Journal of Mechanical and Civil Engineering, 3(3), pp. 37-51.

Chen, J. J., \& Chambers, D. (1999). Sustainability and the impact of Chinese policy initiates upon construction. Construction Management and Economics, 17(5), pp. 679-687.

Chileshe, N. (2011). Delivering sustainability through construction and project management: practices, tools and practices. In: Roetman, P. E. J., \& Daniels, C. B. (eds.), Creating Sustainable Communities in a Changing World, 1st edn. Chapter: 13. Crawford House Publishing, South Australia, pp. 111-118.

Chin, T. A., Tat, H. H., \& Sulaiman, Z. (2015). Green supply chain management, environmental collaboration and sustainability performance. Procedia CIRP, 26(2015), pp. 695-699.

Ching, F. D. K., and Winkel, S. R. (2016). Building Codes Illustrated: A Guide to Understanding the 2015 International Building Code, 5th edn. John Wiley \& Sons, Hoboken, New Jersey, ISBN: 978-1-119-15092-3.

Chopra, S., \& Meindl, P. (2013). Supply Chain Management Strategy, Planning and Operation. Prentice Hall-Pearson, New York, USA.

Christopher, M. (1998). Logistics and Supply Chain Management: Strategies for Reducing Cost and Improving Service. Financial Times Pitman Publishing, London.

CIB. (1996). Towards a 30 per cent Productivity Improvement in Construction, (Working Group 11). Construction Industry Board, Tomas Telford, London.

CIC. (1994). Dispute Resolution, a Report by the Dispute Resolution Task Force of the Construction Industry Council Which Identifies the Disputes That Arise in the Construction Industry and Existing Methods of Their Resolution. Construction Industry Council, London.

Cox, A., \& Townsend, M. (1998). Strategic Procurement in Construction. Thomas Telford Publishing. ISBN-10: 0727725998.

Craig, N., \& Sommerville, J. (2006). Information management systems on construction projects case study. Records Management Journal, 16(3), pp. 131-148.

Czaja, R., \& Blair, J. (1996). Designing Surveys: A Guide to Decisions and Procedures. Pine Forge Press, London.

De Vaus, D. A. (1990). Survey in Social Research, 2nd ed. Unwin-Hyman, London.

EDMS. (2007). Framework. Engineering Data Management Service. [Online]. Available at http://cedar.web.cern.ch/CEDAR/ glossary.html\#Framework. [Accessed 2 August, 2019].

Edum-Fotwe, F. T., Thorpe, A., \& McCaffer, R. (1999). Organisational relationships within the construction supply-chain. Proceedings of a Joint CIB Triennial Symposium. Cape Town: Sloan Management Review, 33(3), pp. 65-73.

EES. (2018). Egyptian Engineers Syndicate. [Online]. Available at http://eea.org.eg/ [accessed 12 October, 2018].

Elfving, J. A., Tommelein, I. D., \& Ballard G. (2005). Consequences of competitive bidding in project-based production. Journal of Purchasing and Supply Management, 11(4), pp. 173-181.

Essam, M., \& Ehab, M. (2015). Construction Supply Chain, Inter-Sectoral Linkagesand Contribution To Economic Growth: the case study Egypt. The Egyptian Center For Economic study, Working Paper No. 184. [Online]. Available at http://www.eces. org.eg/MediaFiles/Uploaded_Files/5c2eab3f.pdf [accessed 8 September, 2019].
Field, B., \& Ofori, G. (1988). Construction and economic development - a case study. Third World Planning Review, 10(1), pp. 41-50.

FluidSurveys Team. (2014). Calculating the Right Survey Sample Size. [Online]. Available at http://fluidsurveys.com/university/ calculating-right-survey-sample-size/ [accessed 2 April, 2018].

Friends of the Earth. (1995). Prescription for Change: Health and the Environment. Friend of the Earth, Brussels.

Goral, J. (2007). Risk management in the conceptual design phase of building projects. Master's thesis in the International Master's Programme Structural Engineering 2007, Chalmers University of Technology, Göteborg.

Greenwood, D. J. (2004). The North Tyneside Partnering Agreement: a study of Strategic Partnering in the Public Sector. Research Report carried out for the Department of Trade and Industry by Northumbria University.

Guo, L., Li, H., \& Zhang, C. (2016). Transaction costs in construction projects under uncertainty. Kybernetes, 45(6), pp. 866-883, 20.

Hannagan, T. J. (1986). Mastering Statistics, 2nd edn. Macmillan Education Ltd, London.

ICE. (1996a). Design and Practice Guide: Creating Value in Engineering. The Institute of Civil Engineers, Thomas Telford, London.

ICE. (1996b). Civil Engineering Procedure, 5th edn. The Institute of Civil Engineers, Thomas Telford, London.

Karlsson, I. (2009). Social and Economic Aspects of Sustainable Development. Uppsala University, Sweden: The Baltic University Programme, Uppsala Centre for Sustainable Development.

Katunzi, T. M. (2011). Obstacles to process integration along the supply chain: Manufacturing firms perspective international. Journal of Business and Management, 6(5), 105-113.

Khan, R. A. (2008). Role of construction sector in economic growth: Empirical evidence from Pakistan economy. In: Proceedings of the First International Conference on Construction in Developing Countries (ICCIDC), Karachi, Pakistan, August 2008, pp. 279-290.

Khan, S. A. (2019). Global Perspectives on Green Business Administration and Sustainable Supply Chain Management. ISBN: 9781799821731, IGI Global Publisher USA.

Kim, J. (1998). Sustainable Architecture Module: Introduction to Sustainable Design. National Pollution Prevention Centre for Higher Education, University Ave., Ann Arbor, MI 48109-1115.

Kubal, M. T. (1994). Engineering Quality in Construction. McGraw-Hill, New York, NY.

Lawson, B., Krause, D., \& Potter, A. (2014). Improving supplier new product development performance: The role of supplier development. Journal of Product Innovation Management, 32(5), pp. 777-792.

Love, P. E. D., \& Edwards, D. J. (2004). Forensic project management: the underlying causes of rework in construction projects. Civil Environmental Engineering Systems, 12(3), pp. 207-228.

Love, P. E. D., \& Li, H. (2000). Quantifying the causes and costs of rework in construction. Construction Management Economics, 18(4), 479-490.

Marquez, A. C. (2010). Dynamic modelling for supply chain management: dealing with front-end, back-end and integration issues. Springer, ISBN-13: 978-1848826809.

Marshall, R. D., Pfrang, E. O., Leyendecker, E. V., Woodward, K. A., Reed, R. P., Kasen, M. B., et al. (1982). Investigation of 
the Kansas City Hyatt Regency walkways collapse. Building Science Series. 143. U.S. Dept. of Commerce, National Bureau of Standards. Retrieved 17 February, 2018.

MaSC. (2002). Managing sustainable construction - Profiting from sustainability. Available at www.bre.co.uk [accessed 9 September 2019].

Mentzer, J. T., Dewitt, W., Keebler, J. S., Min, S., Nix, N. W., Smith, C. D., et al. (2001). What is supply chain management? In: Mentzer, J. T. (ed.), Supply Chain Management. Sage Publications, Inc, California, Michigan, pp. 1-25.

Kometa, S. T., \& Olomolaiye, P. O. (1997). Evaluation of factors influencing construction clients' decision to build. Journal of Management in Engineering, 3(2), pp. 77-86.

Northey, G. (2018). An Introduction to Early Supplier Involvement in the Construction Industry. Available at https://www. buildingsolutions.com/industry-insights/introduction-to-earlier-supplier- involvement-in-the-construction-industry [Retrieved 20 November, 2019, from CRH Americas, Inc.].

Norton, B. R., \& McElligott, W. C. (1995). Value Management in Construction: A Practical Guide. Macmillan, London.

O’Brien, J. J. (1998). Construction Change Orders. McGraw-Hill, New York, NY.

O'Brien, W. J., \& Fischer, M. A. (1993). Construction supply-chain management: a research framework. In: Proceedings of CIVIL-COMP-'93, Information Technology for Civil and Structural Engineers, The Third International Conference on the Application of Artificial Intelligence to Civil and Structural Engineers, Edinburgh, Scotland, 17-19 August, pp. 61-64.

O'Leary, A. (1992). Construction Administration in Architectural Practice, 1st ed., McGraw-Hill, New York, NY.

Olomolaiye, P. O., Price, A. D. F., \& Wahab, K. A. (1987). Problems influencing craftsmen's productivity in Nigeria build. Environment, 22(4), pp. 317-323.

Othman, A. A. E. (2008). Building the effective architectural team in design firms: The case of the United Arab Emirates. Emirates Journal for Engineering Research, 13(1), pp. 1-11.

Othman, A. A. E., \& Abdelwahab, N. M. (2016). A field study investigating the role of integrating risk management into the architectural design process as an approach towards delivering sustainable construction projects. In: Proceedings of the 10th Built Environment Conference, Port Elizabeth, 31 July-2 August, pp. 261-272, ISBN number: 978-0-620-71904-9.

Othman, A. A. E., \& El-Gendawy, A. H. S. (2010). Improving construction sustainability through integrating suppliers and manufacturers in the design process. In: Proceedings of the 2nd International Conference on Construction In Developing Countries (ICCDC-II) "Advancing and Integrating Construction Education, Research \& Practice" 3-5 August 2010, Cairo, Egypt, pp. 119-134.

Othman, A. A. E., \& Nadim, W. (2010). Towards establishing an international sustainability index for the construction industry: A literature review. In: Proceedings of the First International Conference on Sustainability and the Future, The British University, Cairo, 23-25 November, pp. 222-235.

Othman, A. A. E., \& Sokkar, D. A. (2019). Enhancing the performance of architectural design firms through addressing the gap of workforce skills in developing countries: A good-to-great approach. Organisation, Technology and Management in Construction: An International Journal, 11(1), pp. 1911-1924.
Othman, A. A. E., Ghaly, M., \& ZainulAbidin, N. (2014). Lean principles: An innovative approach for achieving sustainability in the egyptian construction industry. Organisation, Technology and Management in Construction: An International Journal, 6(1), pp. 917-932.

Othman, A., \& Harinarain, N. (2009). Managing risks associated with the JBCC(principal building agreement) from theSouth African contractor's perspective. Acta Structilia, 16(1), pp. 83-119.

Parkin, S., Sommer, F., \& Uren, S. (2003). Sustainable development: Understanding the concept and practical challenge. Proceedings of the Institution of Civil Engineers, Engineering Sustainability, 156(1), pp. 19-26.

RIBA. (2013). RIBA Plan of Work 2013. Royal Institute of British Architects, London.

Richardson, S. (2007). What Is a skill shortage? National Centre for Vocational Education Research, Adelaide, Australia. Available at https://www.ncver.edu.au/research-and- statistics/ publications/all-publications/what-is-a-skill-shortage on [Accessed 15 September, 2018].

Rodriguez, S., Roman, M., Sturhahn, S., \& Terry, E. (2002). Sustainability assessment and reporting for the University of Michigan's Ann Arbor Campus. Master's Thesis. University of Michigan, Ann Arbor, pp. 1-396.

Roodman, D. M., \& Lenssen, N. A. (1995). Building revolution: How ecology health concerns are transforming construction. Paper 124. World Watch Institute, Washington, DC.

Sarkis, J. (2014). Green Supply Chain Management. Momentum Press, New York City.

Segerstedt, A., \& Olofsson, T. (2010). Supply chains in the construction industry. Supply Chain Management, 15(5), pp. 347-353.

Shash, A. A. (1993). Factors considered in tendering decisions by top UK contractors. Construction Management and Economics, 11(2), pp. 111-118.

Simangunsong, E., Hendry, L. C., \& Stevens, M. (2016). Managing supply chain uncertainty with emerging ethical issues. International Journal of Operations \& Production Management, 36(10), pp. 1272-1307.

Sisco, C., Chorn, B., \& Pruzan, P. M. (2010). Supply Chain Sustainability A Practical Guide. UN Global Compact and Business for Social Responsibility, p. 68.

Smith, J., \& Wyatt, R. (1998). Criteria for strategic decision making at the pre-briefing stage. In: Hughes, W. (ed.), Association of Research in Construction Management (ARCOM), Proceedings of the 14th Annual. Conference, 9-11 September, Reading University, UK, pp. 300-309.

Subramani, T., Sruthi, P. S., \& Kavitha, M. (2014). Causes of cost overrun in construction. IOSR Journal of Engineering, 4(6), pp. 1-7.

The National Economic Development Office. (1987). Achieving Quality on Building Sites. National Economic Development Office, London, pp. 18-19.

Thunberg, M., Rudberg, M., \& Gustavsson, T. K. (2017). Categorising on-site problems: A supply chain management perspective. Construction Innovation, 17(1), pp. 90-111.

USEPA. (2009). Basic Information. The United States Environmental Protection Agency (USEPA). [Online]. Available at http://www. epa.gov/sustainability/basicinfo.htm [accessed 29 August, 2019]. 
Valdés-Rodríguez, O. A., \& Pérez-Vázque, A. (2011). Sustainable livelihoods: An analysis of the methodology [Modos De Vida Sustentable: Un Análisis De Las Metodologías]. Tropical and Subtropical Agroecosystems, 14(2011), pp. 91-99.

Veenendaal, J. (1998). Analysing the impact of change orders on a schedule. Cost Engineering, 40(9), pp. 33-39.

Vrijhoef, R. (1998). Co-makership in construction: Towards construction supply chain management. MSc thesis, Delft University of Technology, Delft.

Vrijhoef, R., \& Koskela, L. (2000). The four roles of supply chain management in construction. European Journal of Purchasing \& Supply Management, 6(2000), pp. 169-178.

Wantanakorn, D., Mawdesley, M. J., \& Askew, W. H. (1999). Management errors in construction. Engineering, Construction and Architectural Management, 6(2), pp. 112-120.
Whyte, A., \& Scott, D. (2010). Life-cycle costing analysis to assist design decisions: Beyond 3D building information modelling. In: Proceedings of the International Conference on Computing in Civil and Building Engineering, University of Nottingham.

Willmott Dixon Group. (2015). Willmott Dixon Group. [Online]. Available at http://www.willmottdixon.co.uk/contact [Accessed 15 March, 2019].

World Commission on Environment and Development. (1987). Our Common Future. Oxford University Press, Oxford.

WS Atkins Consultants. (2001), Sustainable Construction: Company Indicator, CIRIA C563, CIRIA, London.

Xie, C., Wu, D., \& Hu, X. (2010). A case study of multi-team communications in construction design. Supply Chain Management, 15(5), pp. 363-370. 